\title{
Integrating In Situ Measurements and City Scale Modelling to Assess the COVID-19 Lockdown Effects on Emissions and Air Quality in Athens, Greece
}

\author{
Georgios Grivas ${ }^{1, *}$, Eleni Athanasopoulou ${ }^{1}$ (D), Anastasia Kakouri ${ }^{1}$, Jennifer Bailey ${ }^{1}$, \\ Eleni Liakakou ${ }^{1}$, Iasonas Stavroulas ${ }^{1}$, Panayiotis Kalkavouras ${ }^{1}$, Aikaterini Bougiatioti ${ }^{1}$, \\ Dimitris G. Kaskaoutis ${ }^{1,2}{ }^{1}$, Michel Ramonet ${ }^{3}\left(\mathbb{D}\right.$, Nikolaos Mihalopoulos ${ }^{1,2}(\mathbb{D})$ and \\ Evangelos Gerasopoulos $1, *$ \\ 1 Institute for Environmental Research and Sustainable Development, National Observatory of Athens, \\ 15236 Athens, Greece; eathana@noa.gr (E.A.); nkakouri@noa.gr (A.K.); jbailey@noa.gr (J.B.); \\ liakakou@noa.gr (E.L.); i.stavroulas@noa.gr (I.S.); pkalkas@phys.uoa.gr (P.K.); abougiat@noa.gr (A.B.); \\ dkask@noa.gr (D.G.K.); nmihalo@noa.gr (N.M.) \\ 2 Environmental Chemical Processes Laboratory, Department of Chemistry, University of Crete, \\ 70013 Heraklion, Greece \\ 3 Laboratoire des Sciences du Climat et de l'Environnement, LSCE-IPSL (CEA-CNRS-UVSQ), \\ Université Paris-Saclay, 91190 Gif-sur-Yvette, France; michel.ramonet@lsce.ipsl.fr \\ * Correspondence: ggrivas@noa.gr (G.G.); egera@noa.gr (E.G.); \\ Tel.: +30-2108109219 (G.G.); +30-2108109124 (E.G.)
}

Received: 23 September 2020; Accepted: 28 October 2020; Published: 30 October 2020

\begin{abstract}
The lockdown measures implemented worldwide to slow the spread of the COVID-19 pandemic have allowed for a unique real-world experiment, regarding the impacts of drastic emission cutbacks on urban air quality. In this study we assess the effects of a 7-week (23 March-10 May 2020) lockdown in the Greater Area of Athens, coupling in situ observations with estimations from a meteorology-atmospheric chemistry model. Measurements in central Athens during the lockdown were compared with levels during the pre- and post-lockdown 3-week periods and with respective levels in the four previous years. We examined regulatory pollutants as well as $\mathrm{CO}_{2}$, black carbon (BC) and source-specific BC components. Models were run for pre-lockdown and lockdown periods, under baseline and reduced-emissions scenarios. The in-situ results indicate mean concentration reductions of 30-35\% for traffic-related pollutants in Athens $\left(\mathrm{NO}_{2}, \mathrm{CO}, \mathrm{BC}\right.$ from fossil fuel combustion), compared to the pre-lockdown period. A large reduction (53\%) was observed also for the urban $\mathrm{CO}_{2}$ enhancement while the reduction for $\mathrm{PM}_{2.5}$ was subtler (18\%). Significant reductions were also observed when comparing the 2020 lockdown period with past years. However, levels rebounded immediately following the lift of the general lockdown. The decrease in measured $\mathrm{NO}_{2}$ concentrations was reproduced by the implementation of the city scale model, under a realistic reduced-emissions scenario for the lockdown period, anchored at a $46 \%$ decline of road transport activity. The model permitted the assessment of air quality improvements on a spatial scale, indicating that $\mathrm{NO}_{2}$ mean concentration reductions in areas of the Athens basin reached up to $50 \%$. The findings suggest a potential for local traffic management strategies to reduce ambient exposure and to minimize exceedances of air quality standards for primary pollutants.
\end{abstract}

Keywords: pandemic; urban air pollution; traffic; chemical transport model; TAPM; mapping 


\section{Introduction}

A pneumonia of unknown cause was detected in Wuhan, China at the end of December 2019. This was found to be caused by a newly discovered coronavirus (Severe Acute Respiratory Syndrome CoronaVirus 2 or SARS-CoV-2) leading to an outbreak of the infectious coronavirus disease, COVID-19 [1,2]. The outbreak swiftly navigated the globe and was declared as a pandemic by the World Health Organization (WHO) on 11 March 2020. In Europe, the first cases were reported by the end of January, with the first confirmed SARS-CoV-2 case in Greece announced on 26 February [3]. To date (24 October 2020) the total number of confirmed cases in Greece approaches 30,000, resulting in more than 500 deaths. The region of Attica, including Athens, the capital and largest city of Greece, is the area with the highest number of cases ( $45 \%$ of cases confirmed nationwide) [4].

Most people infected with the virus will experience mild symptoms, but a considerable number of cases will require hospitalization and may develop fatal complications $[5,6]$. The WHO, considering the primary spread mechanism of SARS-CoV-2, has suggested to maintain a distance of $1.5-2 \mathrm{~m}$ between people. Moreover, some studies have shown a plausible, indirect, transmission pathway through ambient aerosols [7-9], as the virus can remain viable on aerosols for hours [10]. The current understanding of the virus' transmission has dictated the necessity of physical distancing measures, which have been adopted in various degrees by state authorities around the world.

Following the implementation of confinement measures in countries responding to the COVID-19 pandemic, an improvement of anthropogenic pollution conditions was suggested, at first by satellite observations. Satellite data on $\mathrm{NO}_{2}$ concentrations have shown reductions of up to $30 \%$ in some of the early outbreak epicenters (China, Italy, Eastern USA, etc.) under some form of lockdown [11,12]. It was immediately evident that the consequences of the pandemic had essentially allowed for an unprecedented large-scale experiment to quantify the impact on air quality if the unnecessary use of passenger cars in urban areas was eliminated [13]. In this respect, ground-level ambient measurements using reference instrumentation are essential, as the gold standard to assess concentration levels and regulatory compliance [14]. Furthermore, the continuous assessment of air quality variations during the COVID-19 outbreak periods is critical, since short-term exposure to elevated pollutant concentrations has been linked to increased risks of infection $[15,16]$.

A number of studies analyzing in situ air quality data during the pandemic period have reported results from China and other Asian countries [17-20]. In Europe, the first studies were from Southern European countries that applied large-scale confinement measures from the outset to counter the rapidly spreading disease [13,21-23]. The observed reductions in pollutant levels are associated with corresponding reductions in the intensity of emission sources. However, a quantitative assessment of these effects, which can function as a roadmap for future air pollution mitigation strategies, requires also a modelling approach. As the observed changes are also influenced by meteorological variability and potential inter-annual emission trends, some recent model sensitivity experiments have aimed to isolate the fingerprint of lockdown measures on air pollution [24].

In this study, we evaluate the effects of the lockdown on air quality in Athens, Greece-an urban area with over 3 million inhabitants and a history of aggravated air pollution [25-28] — by analyzing the changes during its enforcement, in comparison to the pre- and post- lockdown periods. The analysis is also expanded to the four previous years, for the respective periods, allowing for a more comprehensive consideration of the possible effects of short- and long-term fluctuations in emissions and meteorological conditions. The study is focused on regulated pollutants that have local primary emission sources-mostly related to vehicular traffic-in Athens $\left(\mathrm{CO}, \mathrm{NO}_{2}, \mathrm{PM}_{2.5}\right)$ and also includes parameters that have not been thoroughly examined yet by studies on COVID-19 effects, such as urban $\mathrm{CO}_{2}$, black carbon (BC) and $\mathrm{BC}$ components related to fossil-fuel and biomass burning. In parallel with in situ observations, we apply and validate a coupled meteorology-chemistry model (TAPM) to simulate pollutant concentrations in high spatial resolution-with an emphasis on NO2-under the assumptions of emission reduction scenarios and against a business-as-usual baseline. This permitted 
to estimate the fraction of observed mean concentration changes that was associated with reduced human activity during the lockdown period.

\section{Study Area and Methods}

\subsection{Lockdown Measures in Greece and Selection of Study Periods}

In Greece, containment measures were implemented as early as 27 February, first at the local and regional levels (e.g., cancellation of carnival events). The restrictions were gradually expanded nationwide including closing buildings of all educational institutions on $10 \mathrm{March}$, closing all food service establishments, shopping centers and sports facilities on 13 March and closing commercial stores on 16 March. Given the minor impact of this partial lockdown on the mobility of citizens, it was quickly upgraded to a general lockdown on 23 March. Along with the general provisions for social distancing, the use of personal vehicles was prohibited with the exception of commuting to workplaces, health facilities and essential goods suppliers (e.g., supermarkets, drugstores, gas stations). Public transportation also worked on a less frequent schedule while passenger vehicle transportation outside the regional boundaries was forbidden [3,29].

During the lockdown period, an effective decrease in the mobility of citizens was recorded, exceeding $50 \%$ on average for movement to retail and recreation facilities and workplaces in Attica [30]. With the SARS-CoV-2 spread coming under control and an observed decrease in the rate of new infections [29], the phasing out of the measures began on 4 May, when free circulation of passenger vehicles within the boundaries of each regional administrative unit was allowed unconditionally. On 11 May, which is considered the start of the post-lockdown period in Greece [31], a large number of citizens returned to their workplaces and commercial activity recommenced with the opening of a large portion of commercial facilities.

The present analysis for in-situ measurements $\left(\mathrm{NO}_{2}, \mathrm{CO}, \mathrm{CO}_{2}, \mathrm{BC}\right.$ and components, $\left.\mathrm{PM}_{2.5}\right)$ covers the full period of Spring 2020. Regarding the analysis of in situ measurement results, the examined lockdown period is determined from 23 March to 10 May, the pre-lockdown period is 1-22 March (earlier measurements during winter were not considered in order to avoid overtly confounding the results with the impact of residential heating emissions) and the post-lockdown period is 11-31 May [31]. Moreover, the levels of $\mathrm{NO}_{2}$ and $\mathrm{BC}$ components are examined during the respective periods in the four previous years to better characterize observed changes in 2020. Regarding the analysis of modeling results, the simulations in 2019 and 2020 cover the months of March and April, with the lockdown period beginning in 23 March, in line with the analysis of in situ measurements.

\subsection{Sites and Measurement Periods}

The Athens basin $\left(450 \mathrm{~km}^{2}\right)$, bound by medium-altitude mountains and by the Saronic Gulf to the south-southwest, concentrates the majority of the population (3.1 of 3.8 million) and economic activity of the Greater Area of Athens (GAA) in the region of Attica, Greece (Figure 1). A large number (over 2.8 million) of vehicles is registered in Attica, of which the large majority (approximately 90\%) are gasoline-powered private cars. The vehicle fleet also includes over 100,000 diesel-powered light- and heavy-duty vehicles, buses and taxies [32]. After the long-standing ban on private diesel-powered cars was lifted in 2011, new registrations ensued at an increased rate with respect to gasoline-powered cars, however, their participation to the total passenger fleet is relatively small up to now [33]. While the majority of households still use heating oil or natural gas as space heating fuel during the winter months, since 2012 and due to the recession in Greece, the use of wood in fireplaces and stoves increased dramatically $[26,34]$, leading to pronounced wintertime air quality events, especially regarding particle pollutants [35-37]. A much smaller contribution of wood-burning emissions has been observed during March and April compared to the winter months, during the past six years [28]. The major non-traffic, non-heating, activity affecting the Athens basin is shipping at and around the port of Piraeus, the largest passenger port in Europe (although passenger traffic is typically reduced in the vacation off-season) 
and the second-busiest container port in the Mediterranean. Industrial activity inside the Athens basin is limited [27].
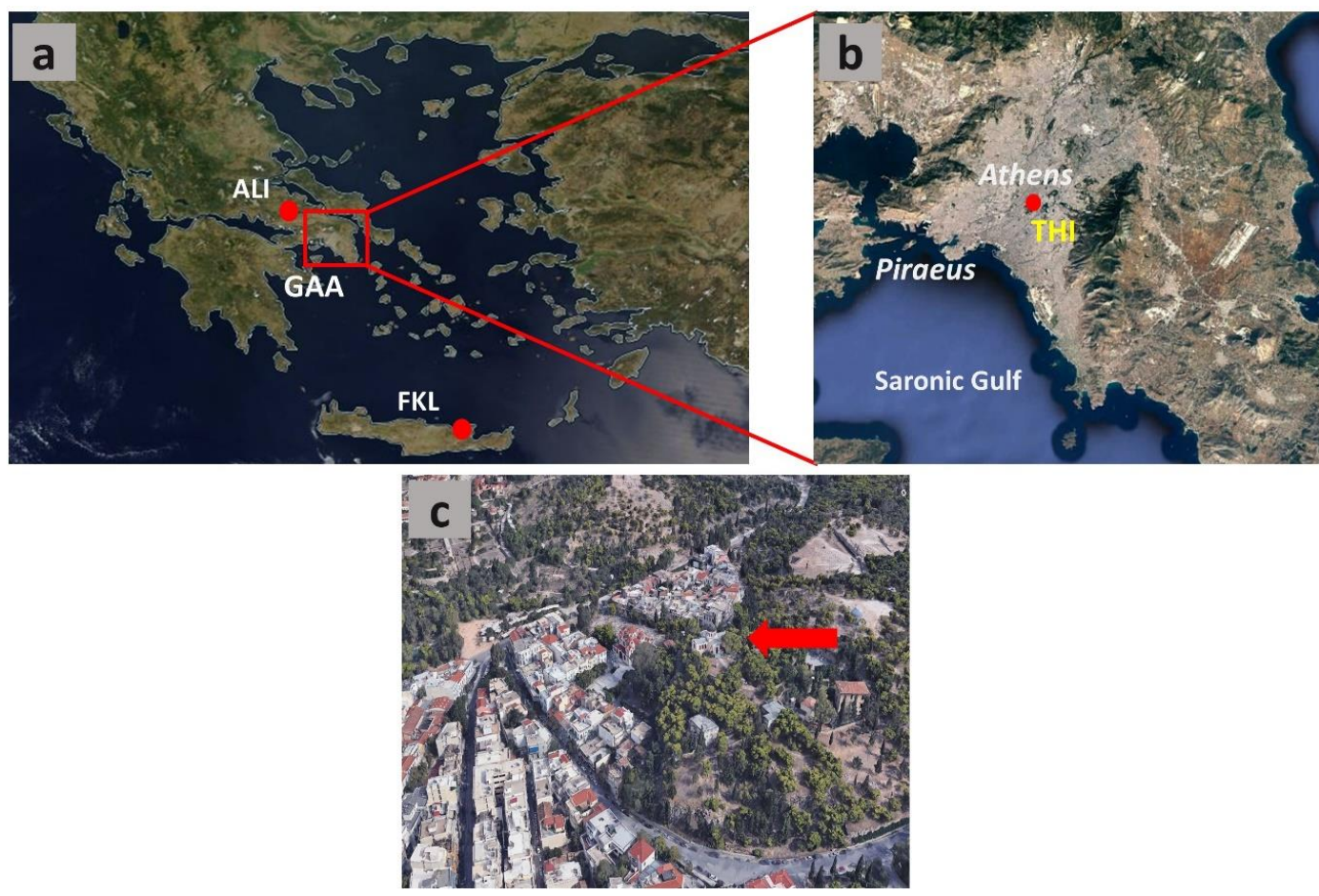

Figure 1. (a) Satellite overview of mainland and insular Greece, indicating the Greater Area of Athens (GAA) and the EMEP regional background sites of Finokalia, Crete (FKL) and Aliartos, Central Greece (ALI); (b) Overview of the GAA indicating the urban background Thissio (THI) site in the Athens basin; (c) Near view of the Thissio Air Monitoring Station atop the Nymphs Hill, in central Athens. Source: Google Earth, 10 August 2020.

The climate in the area of Athens is Mediterranean-type, with relatively dry springs. Due to the topographical features of the Athens basin, winds flow mainly along the SW-NE axis. In March and April, strong northerly flows, effective throughout the day, are the dominant regime, while weak daytime southerly flows are also frequently observed. In May, strong northerly winds are mostly confined in daytime, while the prevalent wind regime is associated with sea breeze circulation from southern directions [38]. The average mixing layer height is not expected to display significant variability between the spring months [39].

In situ measurements were conducted at the Thissio (THI) Air Monitoring Station $\left(37.97326^{\circ} \mathrm{N}\right.$, $23.71836^{\circ} \mathrm{E}, 105 \mathrm{~m}$ a.s.1) of the National Observatory of Athens (NOA), located in the historical center of the city. The sampling height was $4 \mathrm{~m}$ above ground. The urban background THI site is not directly affected by traffic sources, since it is surrounded by a pedestrian zone and moderately-populated neighborhoods $[40,41]$ and, therefore, is considered representative of background conditions in the central Athens basin $[26,37,42]$. An overview of the study area and the study site is provided in Figure 1.

\subsection{Measurements at the Central Site}

Continuous monitoring of carbon monoxide $(\mathrm{CO})$ and nitrogen oxides $\left(\mathrm{NO}_{\mathrm{x}}: \mathrm{NO}, \mathrm{NO}_{2}\right)$ was conducted using APMA360 and APNA360 gas analyzers (Horiba Ltd., Kyoto, Japan), respectively, at 1-min resolution. The analyzers are routinely calibrated with certified standards. $\mathrm{PM}_{2.5}$ concentrations were determined by a reference-grade beta attenuation monitor (PX-375, Horiba Ltd.), providing measurements averaged on 3-h intervals. The sample flow (16.7 $\left.\mathrm{L} \mathrm{min}^{-1}\right)$ that was separated using a $\mathrm{PM}_{2.5}$ sharp cut cyclone (VSCC 2.251, BGI Inc.) was pre-heated to limit the 
effects of ambient humidity [43]. Black carbon (BC) concentrations were measured using a dual-spot 7-wavelength AE-33 Aethalometer (Magee Scientific, Berkeley, CA, USA), at 1-min resolution and a flow rate of $5 \mathrm{~L} \mathrm{~min}^{-1}$ [28]. The determination of $\mathrm{BC}$ concentrations is performed at $880 \mathrm{~nm}$. The AE-33 aethalometer provides direct estimates of the $\mathrm{BC}$ fraction deriving from biomass burning (BB\%) by applying the aethalometer model $[44,45]$ in real time, therefore, allowing for the determination of the biomass-burning $\left(\mathrm{BC}_{\mathrm{bb}}\right)$ and fossil-fuel $\left(\mathrm{BC}_{\mathrm{ff}}\right)$ source-specific $\mathrm{BC}$ components. Measurements of $\mathrm{CO}_{2}$ were obtained using a Picarro 2401 (Picarro Inc., Santa Clara, CA, USA) cavity ring-down spectrometer (CRDS). The operation is based on the cavity ring-down measurement principle [46,47], using a laser source and a high-finesse optical cavity for measuring gas concentrations with high precision (10 ppb for $\mathrm{CO}_{2}$ with $1 \mathrm{~s}$ integration time). The same instrument type was operating in parallel at the Finokalia (FKL) regional background EMEP monitoring site in Eastern Crete, Greece, at a distance of $350 \mathrm{~km}$ to the S-SE of Athens over the Aegean Sea (Figure 1). Period average (pre-lockdown, lockdown, post-lockdown) concentrations measured at Finokalia were subtracted from 1-h concentrations measured at Thissio to obtain the urban enhancement of $\mathrm{CO}_{2}\left(\Delta-\mathrm{CO}_{2}\right)$. While a site closer to the Athens basin would have been preferable as a background site to better isolate the contribution of urban emissions to $\mathrm{CO}_{2}$ (as $\Delta-\mathrm{CO}_{2}$ ), this configuration still makes it possible to extract the large-scale contributions responsible for the trends and seasonal cycles of $\mathrm{CO}_{2}$. All pollutant data were processed as hourly-average values (3-h averages for $\mathrm{PM}_{2.5}$ at Thissio). Distributions of examined time-series were examined using the Shapiro-Wilk test and they were found to deviate significantly from normality $(p<0.01)$. Consequently, the non-parametric Mann-Whitney test was applied to test the statistical significance of comparisons between observations in independent dataset samples corresponding to the various periods and years (therefore, it should be noted that the reported test results do not refer directly to comparisons between sample means). Meteorological data used in the study (temperature, relative humidity, wind speed/direction, precipitation and solar radiation) were continuously recorded during the study period, at the meteorological station of NOA in Thissio.

\subsection{Model Configuration and Setup}

The air quality fields over the urban area of Athens were simulated using The Air Pollution Model (TAPM) V4 ([48,49]. TAPM is a prognostic meteorology-dispersion model, capable of predicting the flows important to local-scale air pollution, utilizing a background of larger-scale meteorology provided by synoptic analyses (here from ECMWF ERA5 reanalysis). The meteorological component of TAPM is an incompressible, non-hydrostatic, primitive equation model, with a terrain-following vertical coordinate for three-dimensional simulations.

The air pollution component of TAPM uses the predicted meteorology and turbulence from the meteorological component and consists of: (i) the Eulerian Grid Module (EGM), which solves prognostic equations for the concentration mean and variance; (ii) the Lagrangian Particle Module (LPM) to represent near-source dispersion more accurately; (iii) the Plume Rise Module to account for plume momentum and buoyancy effects for point sources; (iv) the Building Wake Module (not used here).

The model includes a chemistry mode with sulfur and fine particle chemistry $\left(\mathrm{PM}_{10}, \mathrm{NO}_{\mathrm{X}}, \mathrm{NO}_{2}\right.$, $\mathrm{O}_{3}, \mathrm{SO}_{2}, \mathrm{PM}_{2.5}$ ), which is composed of gas-phase photochemical reactions based on the Generic Reaction Set and gas- and aqueous-phase chemical reactions for $\mathrm{SO}_{2}$ and particles. Wet and dry deposition are also simulated. More details on TAPM—overview, equations, parameterizations and verification results—can be found in listed references [50-56].

In this study, the meteorological component of TAPM was used to perform nested simulations with 4 domains centered at $38^{\circ} 2^{\prime} \mathrm{N}, 23^{\circ} 43^{\prime} \mathrm{E}$, with a horizontal grid spacing of $12 \mathrm{~km}$ (parent domain), $4 \mathrm{~km}, 3 \mathrm{~km}$ and $1 \mathrm{~km}$ (innermost domain) and a common vertical structure of 30 terrain-following layers (first layer at $10 \mathrm{~m}$, vertical top height at $8 \mathrm{~km}$ ). Urban area (with the same horizontal resolution), line and point source emissions were produced by a newly developed disaggregation algorithm, successfully tested in Athens [57] and Hamburg (Germany) [58]. The algorithm exploits the regional CAMS-REG-AP emission inventory, re-griding it using contemporary, high-resolution spatial proxies, 
suitable for each source type and sector. The hourly 2-D boundary concentrations were based on regional background in situ measurements at the EMEP sites of Finokalia, Crete and Aliartos, Central Greece (ALI, Figure 1) with the exception of 2020 boundary concentrations for $\mathrm{PM}_{2.5}$, which were provided by a near-city regional background site (VOU, see Section 2.5).

The model was applied for March and April of 2019 and of 2020. A baseline scenario using the conventional emissions, as briefly described above, was implemented for both 2-month periods. For the Greek lockdown emissions scenario implemented here (23 March-30 April 2020), the adopted anthropogenic activity data derive from the thorough estimation approach of Le Quéré et al. [31]. Percent changes in the activity level for each sector are provided therein, not only as global averages but also for European countries including Greece. The extracted indices that have been used to compose the lockdown (confinement level 3) reduced emissions scenario in the present study, are:

- $46 \%$ for road transport (urban congestion index in Europe)

- $35 \%$ for industry (change in coal consumption and/or steel production in China and USA, respectively)

- $85 \%$ in air transport (flight change in the Mediterranean countries of Italy and Spain)

- $2 \%$ in energy (change in the Greek power sector, based on daily electricity load)

\subsection{Ancillary Measurements}

A number of low-cost PM monitors (PA-II, PurpleAir LLC, Draper, UT, USA) have been installed by NOA at residential locations across the Athens basin (in the framework of the national research infrastructure PANACEA), to track the spatial and real-time temporal variability of $\mathrm{PM}_{2.5}$ levels. The devices are calibrated using a multiple regression model against reference instrumentation-since their measurements display a high degree of covariance $\left(R^{2}>0.80\right)$-accounting also for relative humidity effects [43]. The hourly-average recorded/calibrated concentrations from seven devices in March-April 2020 were utilized for the validation of model predictions on a spatial level (all sites are of urban/suburban background type and, therefore, representative for a wider area around their specific location). The monitor at the periphery of the basin (area of Vouliagmeni-VOU) was used to provide boundary $\mathrm{PM}_{2.5}$ concentrations to the model in 2020. The configuration of the low-cost network is displayed in Figure S1 of the Supplementary Material.

\section{Results and Discussion}

\subsection{Representativeness and Influence of Meteorological Conditions}

In order to attribute observed changes of pollutant levels during the lockdown to changes in the intensity of sources, the potential impact of prevailing meteorology has to be examined [18,59]. Consequently, the variability of meteorological parameters, as recorded at the NOA meteorological station in Thissio, was investigated, both during 2020 (March-May) and during the previous years (Table S1 of the Supplementary Material).

As it turns out, the 2020 study period does not present important meteorological irregularities compared to the average patterns of the four previous years. The average horizontal wind speed-an important parameter for the accumulation/dispersion of primary pollutants in the urban environment [26,60,61] —was $2.9 \mathrm{~m} \mathrm{~s}^{-1}$ during 2016-2019 (March-May), almost equal to the corresponding average in $2020\left(3.0 \mathrm{~m} \mathrm{~s}^{-1}\right)$. For precipitation, which can lead to reduced ambient levels especially of particle pollutants, through washout and rainout [62], the total rainfall amounts recorded during the 2016-2019 spring periods were 43-116 $\mathrm{mm}(69 \mathrm{~mm}$ for the pre-lockdown and lockdown periods combined), compared to $105 \mathrm{~mm}$ in Spring 2020 (76 $\mathrm{mm}$ for the pre-lockdown and lockdown periods combined). These levels are generally comparable to the mean spring precipitation calculated by a 150-year record of measurements (1860-2008) at the Thissio meteorological station [63], which, notwithstanding the inter-annual variability, documents relatively stable decadal averages. 
Changes in the mean values of meteorological parameters during 2020, across the three selected periods (before, during and after the lockdown), were moderate and comparable to those observed on average during the previous years, for the same time intervals. In 2020, the average wind speed was similar during the first two periods $\left(3.1 \mathrm{~m} \mathrm{~s}^{-1}\right)$, showing a decrease during the third period $\left(2.5 \mathrm{~m} \mathrm{~s}^{-1}\right)$. Long term observations and synoptic flow analysis for Athens indicate that during May, the area comes under the increased influence of an anticyclonic regime that covers the Eastern Mediterranean while the frequency of closed low pressure systems subsides. Under these conditions, the strong, synoptic-scale northern winds that are observed during March and April become less frequent, giving place to weaker mesoscale winds mainly associated with sea/land breeze circulation [38]. These observations were verified during the 2020 study period, with a prevalence $(>50 \%)$ of northerlies during the pre-lock and lockdown periods and a higher frequency $(62 \%)$ of flows from the southern sector during the post-lockdown days. A reduction in wind speed during the third period was also observed during the previous four years on average, albeit of smaller magnitude. Regarding precipitation, the pattern between the three periods was fairly stable when compared between 2020 and 2016-2019 on average (although there was considerable inter-annual variability). In 2020, the rainfall amount was higher in the lockdown period compared to the non-lockdown periods, but its intensity and frequency, which is a more relevant proxy of atmospheric washout, remained low (10 days with rain during 23 March-10 May 2020 for a cumulative precipitation of $47 \mathrm{~mm}$ ). Days when total rainfall exceeded $10 \mathrm{~mm}$, a threshold over which notable effects on PM concentrations are expected [60], were very infrequent (1, 1 and 2 days for the three successive periods in 2020).

Overall, it can be considered that observed changes in atmospheric pollutant levels during the three examined periods of 2020 - and also in comparison to previous years-should be mainly attributed to changes in the intensity of primary sources rather than to meteorological factors. This argument is discussed and further delineated by the comparison of the model simulations incorporating different emission scenarios before and during the lockdown (Section 3.3). These observations regarding the meteorological effects have implications mainly for primary pollutants from direct emission sources. The concentrations of secondary pollutants, such as ozone, are largely determined by the climatological profile (enhancement of photochemical production during the transition to the summer period) [64] and long range transport, and they are not analyzed in the present study.

\subsection{Changes of Ambient Pollutant Concentration Levels during the Lockdown Period}

The changes in mean concentrations of pollutants during the three periods of 2020 (pre-lockdown, lockdown, post-lockdown) are displayed in Figure 2. For all examined pollutants, there was a decrease during the lockdown period, with changes being statistically significant at least at the 95\% confidence level $(p<0.05)$. Statistics for 2020 concentrations are provided in Table S2 of the Supplementary Material. Average diurnal cycles for pollutant concentrations in the three periods of 2020 are presented in Figure S2 of the Supplementary Material.

For $\mathrm{NO}_{2}$, the average reduction during the lockdown was $32 \%$, compared to the pre-lockdown period. $\mathrm{NO}_{2}$ is a good indicator of primary vehicular emissions in urban areas $[65,66]$ and especially emissions from heavy-duty vehicles, as it has also been shown by emission inventory studies in Athens [32]. Substantial decreases in $\mathrm{NO}_{2}$ levels following the implementation of lockdown measures have been generally reported in large cities, as documented by both ground-level measurements and satellite observations [11,67]. At sites around the world with pollution levels comparable to Thissio, Athens, similar decreases have been reported. For example, an average reduction of approximately $26 \%$ was registered during the first 3 weeks of the lockdown compared to the previous 2 non-lockdown weeks at 2 urban background sites in Rio De Janeiro (Brazil) [68]. Moreover, the reported reduction in Athens is close to the average reduction during the COVID-19 period (31\%) as calculated from data in 121 U.S. counties [14]. However, it was somewhat lower than those reported by similar studies in large European cities. An average reduction of $54 \%$ and $53 \%$ at mostly urban background monitoring sites in Rome and Turin (Italy) was found by Sicard et al. [22] during the respective lockdown periods. 
Tobias et al. [23] documented a $47 \%$ decrease of urban background $\mathrm{NO}_{2}$ concentrations in Barcelona, in the first two weeks following the lockdown in Spain, compared to the previous month. In Madrid, Spain, an average reduction in $\mathrm{NO}_{2}$ concentrations (48\%) at eight urban background locations was reported during the first two lockdown weeks compared to the previous fortnight [13]. Even larger reductions (57-61\%) have been registered for the metropolitan area of Milan, Italy, during the enforcement period of the total lockdown. With the region of Lombardy being an early epicenter of the pandemic outbreak in Europe, the large reductions reflect the severity of the enforced containment measures, that included also suspending most of industrial production [21].
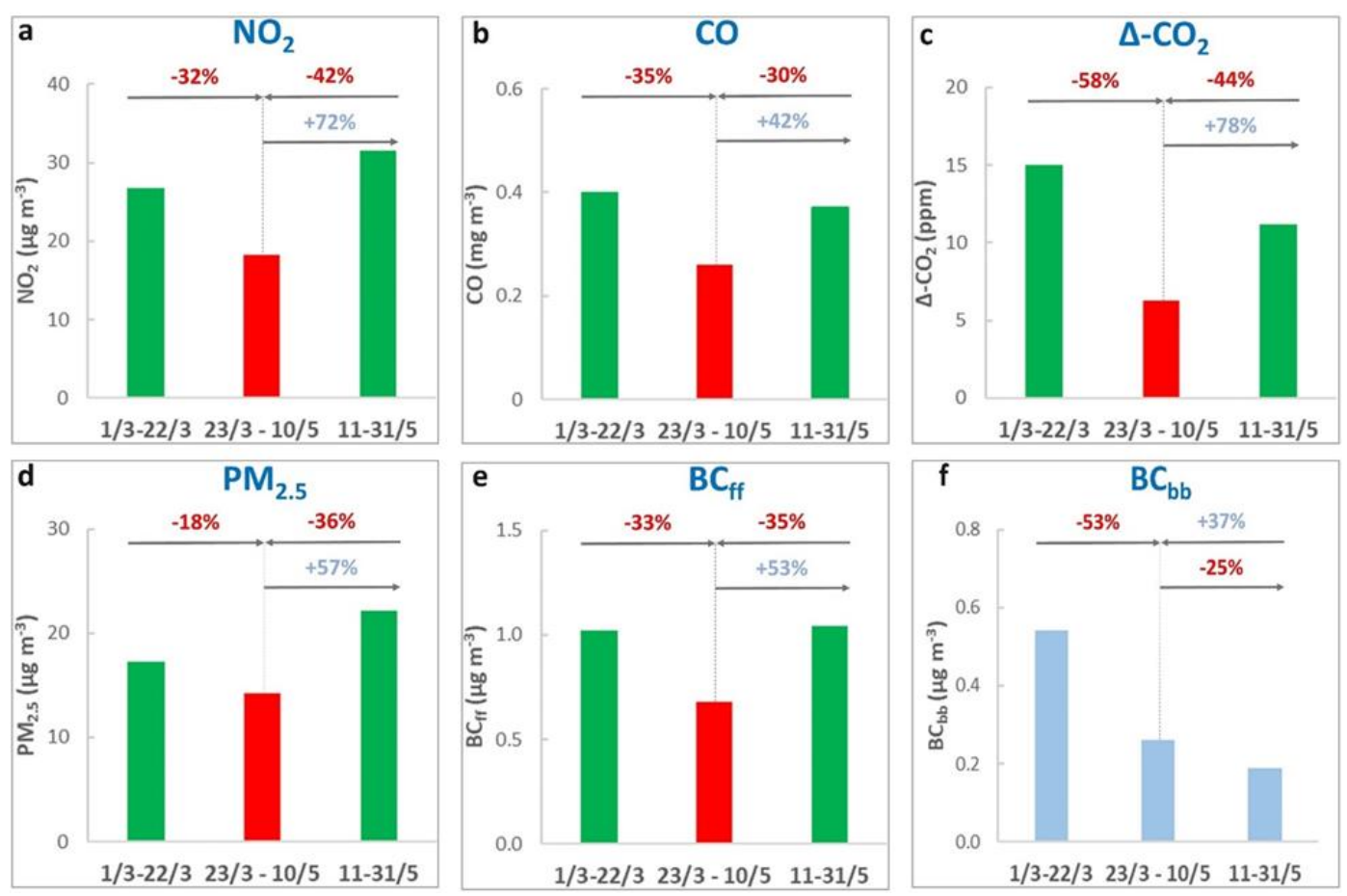

Figure 2. Average concentrations of measured pollutants (a): $\mathrm{NO}_{2},(\mathbf{b}): \mathrm{CO},(\mathbf{d}): \mathrm{PM}_{2.5}$, source-specific black carbon components (e): $\mathrm{BC}_{\mathrm{ff}}(\mathbf{f})$ : $\mathrm{BC}_{\mathrm{bb}}$ and estimated urban enhancement of measured $\mathrm{CO}_{2}(\mathbf{c})$ : $\left.\Delta-\mathrm{CO}_{2}\right)$, for pre-lockdown (1-22 March), lockdown (23 March-10 May) and post-lockdown period (11-31 May) in 2020 at the Thissio site in Athens. Percentages indicate the relative changes between the periods.

CO concentrations were also reduced by $35 \%$, a decrease which, based on the estimated contributions of various sectors in $\mathrm{CO}$ in Athens during the non-heating season, should be attributed mainly to the reduction of emissions from passenger vehicles, light-duty vehicles and two-wheelers $[32,33]$. Indicatively, the reduction of the mean weekly vehicular traffic volumes in the Athens basin during the lockdown period was 40-50\% with respect to the same periods in 2019 (data reported by the Greek Ministry of Infrastructure and Transport, based on measurements from 600 loop detectors in major roads of the city). The comparable percentages for $\mathrm{CO}$ and $\mathrm{NO}_{2}$ reductions at the city-center site implies a similar pattern of decreased activity across categories of the vehicle fleet, although the different contributions of sources other than road transport should be also considered. Nakada and Urban [69] showed similar reductions for $\mathrm{NO}_{2}$ and $\mathrm{CO}$ during the partial lockdown in Sao Paulo, Brazil. However, studies during the total lockdowns in industrialized areas of Hubei, China and Lombardy, Italy $[17,21]$ have reported lower reductions of $\mathrm{CO}$ with respect to $\mathrm{NO}_{2}$, probably indicating an additional effect of reduced emissions of nitrogen oxides from stationary large combustion sources.

Interesting results were obtained for $\mathrm{CO}_{2}$, since, to our knowledge, this is one of the first studies to present ambient $\mathrm{CO}_{2}$ measurements during the COVID-19 period. Average $\mathrm{CO}_{2}$ levels decreased by $2.1 \%(9.1 \mathrm{ppm})$ during the lockdown compared to the pre-lockdown period, a change which, 
although subtle, is still statistically significant at the $99 \%$ confidence level $(p<0.01)$. This reduction is reasonably small compared to other pollutants due to the very long residence time of the greenhouse gas. After subtraction of the respective period-average regional background concentrations and the recalculation for the $\Delta-\mathrm{CO}_{2}$ parameter, the reduction during the lockdown period was $58 \%$, comparable to those observed in major cities internationally, where high-precision methodology is used for $\mathrm{CO}_{2}$ measurement, such as Paris, France and Mexico City, Mexico (Ramonet, unpublished results, 2020). A decrease of anthropogenic $\mathrm{CO}_{2}$ emissions at a global scale during the COVID-19 pandemic period has been predicted by modelling studies, based on realistic scenarios for reduced mobility and production during the confinement period [31,70]. Indicatively, Le Quéré et al. [31] estimated a reduction of 27\% of mean daily $\mathrm{CO}_{2}$ emissions in Greece (2020), within the range of reductions in EU states reported by the same study. The large $\Delta-\mathrm{CO}_{2}$ reduction observed in Athens should be also attributed-to a lesser extent - to the substantial effect of additional sources [71,72] related to the seasonal cycle of residential heating (wood-burning and also combustion of heating oil and natural gas), which-unrelated to lockdown measures-declines up to the end of the heating season in Athens (mid-April) [28]. This is readily evident by the diurnal cycles displayed in Figure S2c of the Supplementary Material, with high nocturnal levels of $\mathrm{CO}_{2}$ during the pre-lockdown period, reflecting the intensity of nighttime residential combustion emissions, combined with the shallow, stable, boundary layer [73]. In the diurnal cycles of the next two periods and, especially, during the post-lockdown period in warm May conditions, this nocturnal plateau is largely absent. These patterns are also present in the diurnal cycles of $\mathrm{NO}_{2}$ and $\mathrm{CO}$ (Figure S2a,b).

The relative variability of traffic and residential biomass burning emissions by period can be illustrated by the evolution of $\mathrm{BC}$ concentrations and its source-specific $\mathrm{BC}_{\mathrm{ff}}, \mathrm{BC}_{\mathrm{bb}}$ components. The $\mathrm{BC}_{\mathrm{ff}}$ fraction, associated with emissions from fossil fuel combustion, which mainly translate to vehicular emissions (Figure S2d of the Supplementary Material) in the area of Athens [28,39], showed a decrease comparable to that of $\mathrm{NO}_{2}$ and $\mathrm{CO}(33 \%$ on average). The respective reduction for the $\mathrm{BC}_{\mathrm{bb}}$ fraction, which is associated with biomass burning almost exclusively for residential heating in Athens during the cold period $[28,40]$ was $53 \%$. Such a reduction is regularly observed in Athens over the last years [28], as can be also seen in the analysis in Section 3.5. Nevertheless, this decrease was obviously independent of the enacted measures and rather related to the gradual deactivation of residential heating as a source, with rising temperatures [42]. This observation becomes evident when examining the diurnal plot in Figure S2e of the Supplementary Material, with $\mathrm{BC}_{\mathrm{bb}}$ initially displaying a typical residential heating nocturnal peak, which becomes much less obvious during the lockdown and is absent in the post-lockdown period. Conversely, the cycles for $\mathrm{BC}_{\mathrm{ff}}$ during the pre-lockdown and lockdown period display mostly a scaling effect with a minimal additional nighttime enhancement, indicating the small effect of heating oil combustion for $\mathrm{BC}_{\mathrm{ff}}$ levels during the late cold period of the year [35]. Overall, the average decrease of BC concentrations during the lockdown was $40 \%$. In comparison, Tobias et al. [22] found a reduction of $45 \%$ at an urban background site during the lockdown in Barcelona, a value also similar to the $\mathrm{NO}_{2}$ reduction in their case. In the greater area of Milan, Collivignarelli et al. [21] reported a large reduction in $\mathrm{BC}$ concentrations reaching 70\%, which they have considered to be representative of the cumulative reduction of road transport mileage in Lombardy.

Regarding fine aerosol $\left(\mathrm{PM}_{2.5}\right)$, a decrease was also recorded (18\% on average), although smaller when compared to other pollutants, but still corresponding to a statistically significant change at the $95 \%$ confidence level $(p<0.05)$. The smaller decrease can be attributed to the multitude of sources and atmospheric processing mechanisms governing $\mathrm{PM}_{2.5}$. Source apportionment studies at the study site $[35,36]$ have established that secondary and regionally transported secondary particles constitute the largest fraction of $\mathrm{PM}_{2.5}$ (exceeding 50\%) and similar contributions have been found at urban/suburban background sites over the Athens basin [27,74]. On the other hand, the contribution of vehicular traffic at background sites in Athens is smaller, in the range of $10-30 \%[27,35,36]$. These are reflected on the relatively flat diurnal cycles for $\mathrm{PM}_{2.5}$ and the absence of a pronounced morning traffic peak (Figure S2f 
of the Supplementary Material), even during the pre-lockdown period. Precursor emissions for these secondary particles-especially $\mathrm{SO}_{2}$ and organics-mainly originate from large scale combustion for energy and industrial production in Northern Greece, the Balkans and Eastern Europe [27,36,75,76]. These emissions are expected to be less reduced in comparison to urban traffic emissions during the lockdown period (for example, a reduction less than $10 \%$ has been reported in the electricity load in the EU-28 countries during the lockdown periods) ([31] and references therein). It is, therefore, reasonable that at urban background sites the cutbacks of traffic emissions will have a smaller footprint on $\mathrm{PM}_{2.5}$ levels. At a global scale, an analysis for the 50 most polluted capital cities has reported an average reduction of $12 \%$ ( $5 \%$ on average for 15 European capitals, not including Athens) for $\mathrm{PM}_{2.5}$ concentrations during the quarantine periods compared to a reference pre-quarantine week [77]. Most studies in urban areas have also reported lower reduction rates for $\mathrm{PM}_{2.5}$ concentrations compared to $\mathrm{NO}_{2}$ and $\mathrm{CO}[14,22,78,79]$.

\subsection{Estimated Changes in Emissions and Spatial Variability of Concentrations for $\mathrm{NO}_{2}$ during the Lockdown}

Given the general absence of real-time anthropogenic emission data, a modeling approach was devised to match the observed concentration levels to a realistic emission reduction scenario. The initial step of this task was to assess the model's ability to reproduce the hourly concentration values in Athens. The evaluation was performed by comparing the model outputs to available measurements (Sections 2.3 and 2.5) and calculating the mean bias (MB), the normalized mean bias (NMB), the squared correlation coefficient $\left(r^{2}\right)$ and the Index of Agreement for $\mathrm{NO}_{2}$ and $\mathrm{PM}_{2.5}$ (Table $\mathrm{S} 3$ of the Supplementary Material). Both 2-month periods (March-April) of 2019 and 2020 (Section 2.4) were used for the evaluation for $\mathrm{NO}_{2}$ estimates, using the appropriate emission approximations (a baseline emissions scenario for non-lockdown days and a reduced emissions scenario during the lockdown). Overall, the model tended to overestimate $\mathrm{NO}_{2}$ and $\mathrm{PM}_{2.5}$ concentrations, with mean $\mathrm{MB}$ values of 1.2 and $6.0 \mu \mathrm{g} \mathrm{m}^{-3}$, respectively (Table S3 of the Supplementary Material). The correlation among the hourly values of predictions and observations ( $r^{2}$ of 0.32 and 0.37 for $\mathrm{NO}_{2}$ and $\mathrm{PM}_{2.5}$, respectively) was statistically significant at the $95 \%$ confidence level $(p<0.05)$ and indicated a fair capability of the model to reproduce the hourly variation of the two pollutants. The NMB value was fairly small for $\mathrm{NO}_{2}(22 \%)$ and moderate for $\mathrm{PM}_{2.5}(44 \%)$. In order to provide a dimensionless measure of model accuracy, the Index of Agreement $(d)$ was also calculated. In the case of $\mathrm{NO}_{2}$ its value was 0.72 , showing a relatively good match with the measured values. For $\mathrm{PM}_{2.5}$, the mean $d$ value was 0.63 . The model performance for this simulation study is consistent with previous TAPM applications in other cities [55,56], as well as with recent model application studies in the area of Athens [42,80].

The resulting changes in emissions were evaluated by assessing the $\mathrm{NO}_{2}$ hourly model performance during the lockdown period (23 March-30 April 2020). Figure 3 depicts $\mathrm{NO}_{2}$ levels at Thissio, as derived from measurements (red dots) and model simulations. The model results correspond to the baseline scenario (conventional emissions from anthropogenic activity) during the pre-lockdown period (blue line) and the lockdown (23 March-30 April) period (blue area), the latter superimposed on results from the lockdown emissions scenario (orange area). The major effects of the confined anthropogenic activity (hourly reductions of more than 8 and up to $28 \mathrm{\mu g} \mathrm{m}^{-3}$ in $\mathrm{NO}_{2}$ levels, when comparing the baseline and reduced emissions scenario) can be seen by the morning and/or evening peaks (typically associated with traffic congestion in central Athens), while milder impacts (less than $3 \mu \mathrm{g} \mathrm{m}^{-3}$ ) are predicted during midday (Figure 3, inserted panel). 


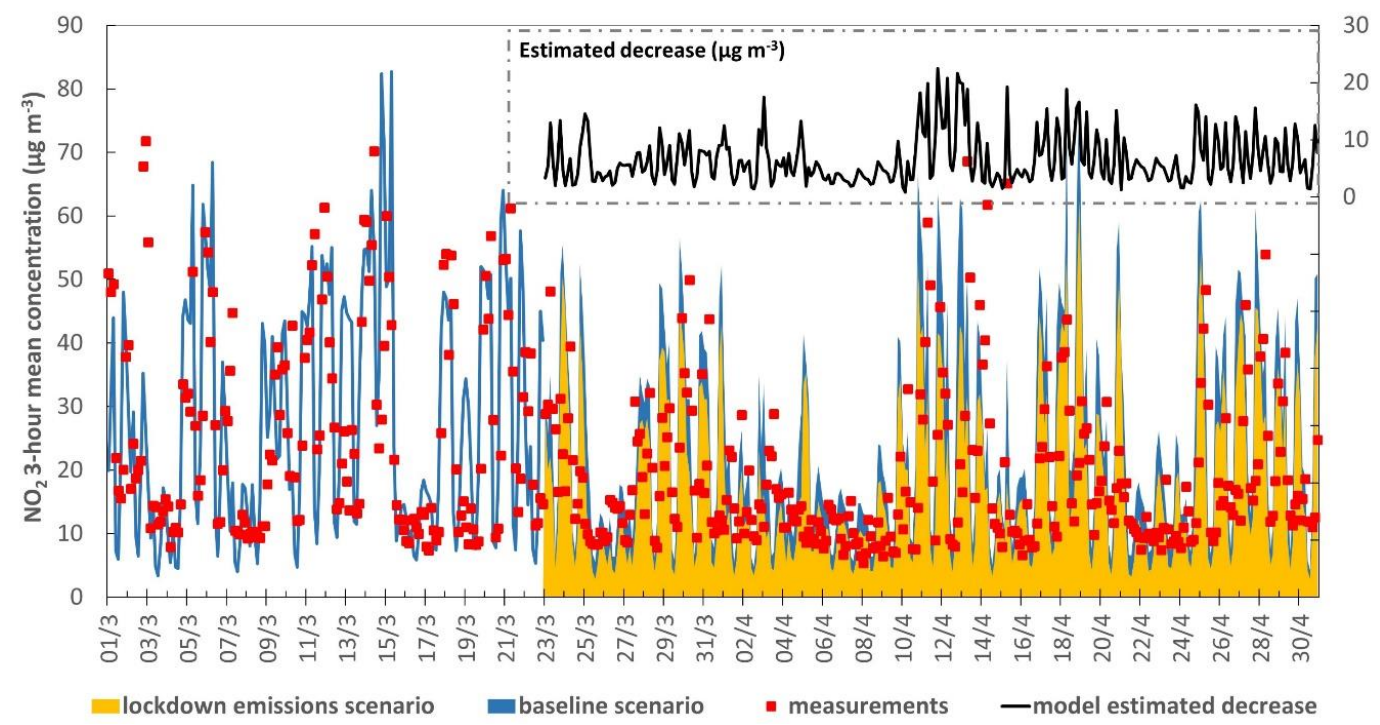

Figure 3. Mean 3-h levels of $\mathrm{NO}_{2}\left(\mu \mathrm{g} \mathrm{m}^{-3}\right)$ in Athens (Thissio), based on measurements (red dots, 1 March-30 April) and city scale model simulations, using conventional emissions (blue line for 1-22 March), combined with a lockdown emissions scenario (orange area for 23 March-30April). The superimposed blue area corresponds to a hypothesis without COVID19-related measures. Also displaying (inserted panel, black line, secondary axis) the estimated net decrease comparing the two scenarios (baseline-lockdown emissions). Tick marks on x-axis correspond to 00:00 UTC + 02:00.

The selected lockdown emissions scenario appears to be justified by modelling results, with the mean predicted value for $\mathrm{NO}_{2}$ at $18.1 \mu \mathrm{g} \mathrm{m}^{-3}$ being comparable to the respective value from in-situ measurements $\left(18.4 \mathrm{\mu g} \mathrm{m}^{-3}\right)$. Given the tailpipe origin of $\mathrm{NO}_{2}$ in urban areas, the assumption of an almost $50 \%$ reduction of vehicular traffic on the road network of Athens (which is also in agreement with reported reduction rates in mobility and actual traffic volumes), appears to be reasonable in order to interpret reduced $\mathrm{NO}_{2}$ levels during the lockdown period.

Consistent with in-situ measurement findings (Section 3.2), the average $\mathrm{NO}_{2}$ concentration during the pre-lockdown simulated period was $28.2 \mathrm{\mu g} \mathrm{m}^{-3}$, indicating a decline of around $10 \mu \mathrm{g} \mathrm{m}^{-3}$ during the lockdown, on average (36\%). The baseline scenario, if applied during the lockdown period, would result in an average $\mathrm{NO}_{2}$ concentration of $24.6 \mu \mathrm{g} \mathrm{m}{ }^{-3}$, i.e., $13 \%$ lower than the actual mean level before the lockdown. This finding might be attributed to the higher precipitation amounts compared to the non-lockdown period, as discussed in Section 3.1. As already argued in the meteorology and in-situ measurement sections (Sections 3.1 and 3.2), the lockdown is confirmed by the model as the dominant factor for this drop in average $\mathrm{NO}_{2}$ levels, with a contribution that is estimated to reach $65 \%$, through the inter-comparison of differences between the baseline and the lockdown emissions scenarios, before and during the lockdown. Excluding the changes in the intensity of primary sources, the remaining $35 \%$ of the mean reduction in $\mathrm{NO}_{2}$ levels can be attributed to the different meteorological conditions during the lockdown, when compared to the pre-lockdown period.

Maps of average $\mathrm{NO}_{2}$ concentrations and concentration differences between the two periods, as predicted by the simulation scenarios in the GAA, are presented in Figure 4. The spatial distribution of $\mathrm{NO}_{2}$ did not change substantially between the pre-lockdown (Figure 4a) and the lockdown period (Figure $4 \mathrm{~b}$ ). The inter-comparison of the two periods (Figure $4 \mathrm{c}$ ) shows a reduction of $30-40 \%$ over the majority of municipalities in the urbanized Athens basin (see discussion in Section 3.2). The mean reduction calculated for the urban center of Athens (red-lined area in Figure 4c) is 27\%. The reduction of $\mathrm{NO}_{2}$ levels over the Athens basin has been also indicated by columnar tropospheric $\mathrm{NO}_{2}$ observations (TROPOMI/Sentinel-5 Precursor), with a monthly average reduction of $9 \%$ between April and March [81]. Among the reasons for the milder difference calculated using satellite data are that the reported value for March contains days with confined anthropogenic activity, and that the 
reported satellite means derive from a column, which horizontally is not confined in the Athens basin but also expands over the sea.

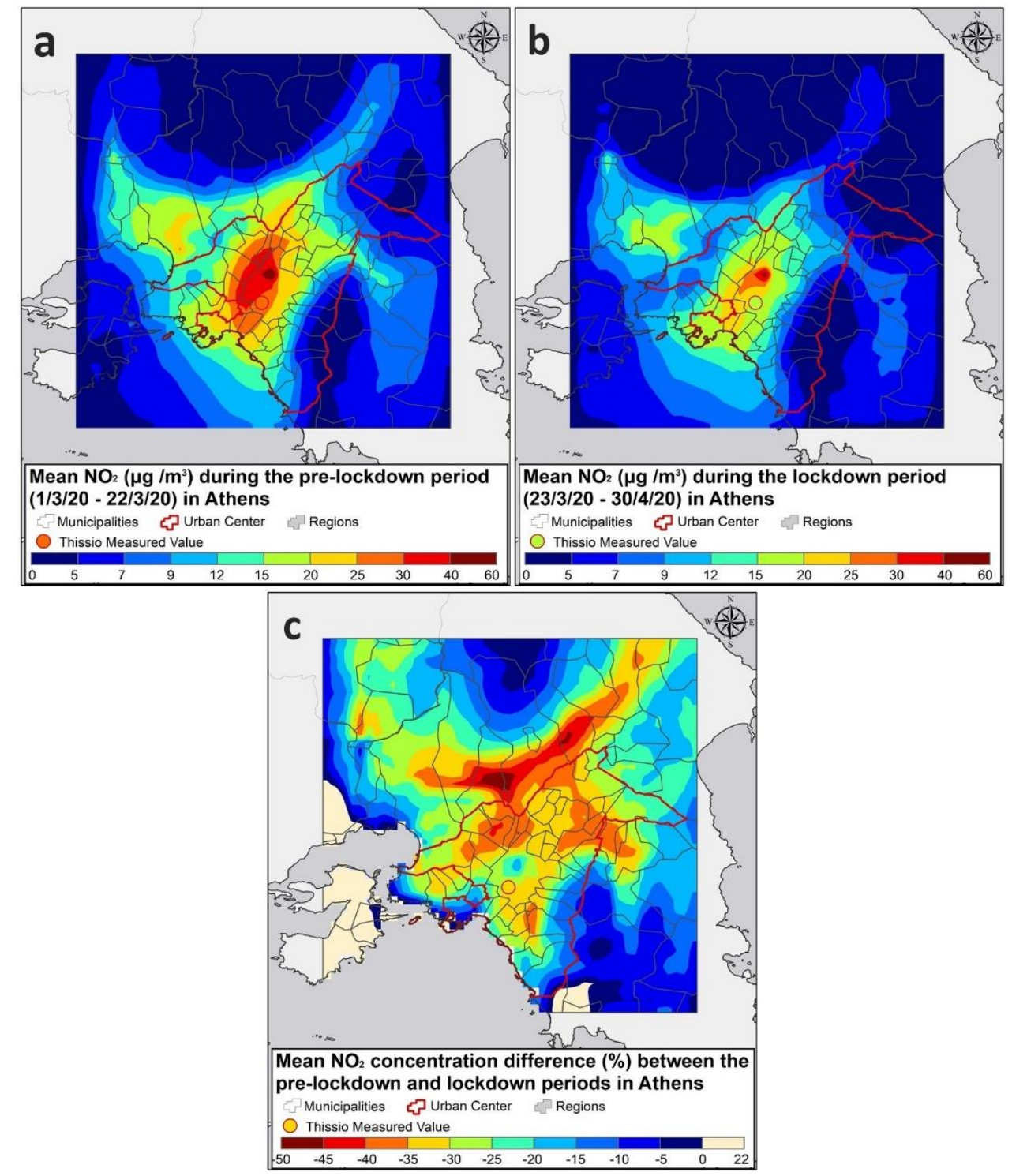

Figure 4. Mean surface $\mathrm{NO}_{2}$ (a) concentrations $\left(\mu \mathrm{g} \mathrm{m}^{-3}\right.$ ) during the pre-lockdown period (March 1-22), (b) concentrations $\left(\mu \mathrm{g} \mathrm{m}^{-3}\right.$ ) during the lockdown (23 March-30 April 2020), (c) percent (\%) changes between the pre- and lockdown periods, as predicted over the Greater Area of Athens (GAA). The location and the mean measured value of the Thissio monitoring site is indicated by a circular colored marker.

The mean measured reduction in $\mathrm{NO}_{2}$ levels at Thissio (31\%) is very close to the mean modelled reduction in the municipality of Athens (29\%), further supporting the representativeness of findings at Thissio for central Athens. Higher reductions (40-50\%) are predicted to the north of the urban center and downhill of the northern mountainous barrier of the Athens basin (Parnitha mountain). These spatially confined maxima should be rather associated with the small displacement of the terrain-dependent concentration gradients during both periods (Figure $4 \mathrm{a}, \mathrm{b}$ ) than to dissimilarities in concentration patterns bound to different local meteorological phenomena. 


\subsection{Recovery of Ambient Pollutant Concentration Levels Following the Lift of Lockdown Measures}

Examining concentration levels during the post-lockdown period, an initial assessment can be made as to whether pollutant levels returned to their typical, for the season, values (Figure 2, Table S2 of the Supplementary Material). It also enabled the validation of the comparison results from the two initial periods (pre-lockdown and lockdown), as in the post-lockdown period there was no longer a confounding influence of domestic heating, which can affect, to a lesser extent, the levels of pollutants regarded here as traffic indicators. It is evident in Figure S2 of the Supplementary Material, that $\mathrm{NO}_{2}$, $\mathrm{CO}, \mathrm{CO}_{2}$, and $\mathrm{BC}_{\mathrm{ff}}$ in the post-lockdown period, register typical bimodal diurnal cycles related to morning and evening rush hours during the warm period in Athens $[26,28,82]$.

Concentration levels rebounded immediately after the end of the lockdown period. The changes in Athens were positive and statistically significant for all examined pollutants, with the obvious exception of $\mathrm{BC}_{\mathrm{bb}}$, which in May decreased further and ranged within regional background levels [37]. Average levels of $\Delta-\mathrm{CO}_{2}$ and $\mathrm{CO}$ increased by $78 \%$ and $40 \%$, respectively, almost reaching their pre-lockdown levels (lower by $25 \%$ and $8 \%$, respectively compared to the pre-lockdown period). The results justify the attribution of the lockdown decreases mainly to the reduction of vehicular emissions and not to the deactivation of the residential heating source. In support of this, a different direction of change for the two $\mathrm{BC}$ fractions was observed, with $\mathrm{BC}_{\mathrm{ff}}$ displaying a $53 \%$ increase and returning to the pre-lockdown mean levels (approximately $1.0 \mu \mathrm{g} \mathrm{m}^{-3}$ ), whereas $\mathrm{BC}_{\mathrm{bb}}$ further decreased to a mean concentration of $0.2 \mu \mathrm{g} \mathrm{m}^{-3}$. The first studies that have reported results following the relaxation of lockdown measures have also indicated the fast reversal of improved air quality conditions that prevailed during the lockdown period [83,84], while also emphasizing the need to consider the effect of site-specific and episodic conditions [85]. In September 2020, the European Environmental Agency (EEA) has announced that pollution reductions were short-lived, with levels of air pollution rebounding as lockdowns were eased and vehicular transport resumed across Europe [86].

Higher increases were observed for $\mathrm{NO}_{2}$ and $\mathrm{PM}_{2.5}$ ( $72 \%$ and $57 \%$ on average, respectively). For $\mathrm{NO}_{2}$, the increase is compatible with the return of a large number of vehicles in circulation and could also indicate more increased circulation of heavy-duty vehicles to supply the commercial sector that resumed operation. However, it should be also noted that during 14-18 May, there was a local photochemical pollution episode in the Athens Basin, characterized by unusually high solar radiation intensity. Indicatively, the total solar radiation during this timeframe in 2020 was by $23 \%$ increased in comparison to the corresponding average value calculated for the four preceding years (26.3 against $21.4 \mathrm{MJ} \mathrm{m}^{-2}$, on a daily basis, respectively). It is likely that the episode resulted in the increased net atmospheric production of $\mathrm{NO}_{2}[82,87,88]$. If the event days (14-18 May) were omitted, a relatively smaller increase would be observed (55\% on average, corresponding to an average concentration of $28.3 \mu \mathrm{g} \mathrm{m}^{-3}$-slightly higher than during the pre-lockdown period). Almost at the same time, there was a notable, regional, African dust transport event, peaking during 15-18 May (see satellite imagery and air mass back-trajectory plot in Figure S3 and Figure S4 of the Supplementary Material, respectively). Such dust episodes, in extreme cases, can inflate also the fine particle fraction, as it is commonly observed during springtime in Athens [89]. If the 15-18 May episode was excluded, the average increase of $\mathrm{PM}_{2.5}$ during the post-lockdown period would be $29 \%$, for an average post-lockdown concentration of $18.4 \mathrm{\mu g} \mathrm{m}^{-3}$ (comparable to pre-lockdown levels).

\subsection{Changes in Concentration Levels in Comparison to Past Years}

To further support that the observed changes were indeed related to the applied measures and not to the seasonal variation profile of emissions or to episodic events, the 2020 concentration time series of $\mathrm{NO}_{2}$ and $\mathrm{BC}$ were compared to those observed during the 4 previous years. Long-term downward trends (e.g., due to pollution abatement policies) are generally considered as a co-factor that can bias this type of analysis [90]. In the case of Athens, existing data of both pollutants do not exhibit significant inter-annual trends for the period after $2016[28,91]$. In order to reduce the noise from day-to-day variability, but also to enable comparison between different years (e.g., by smoothing 
weekend effects), a moving average approach was followed [20]. The 7-day moving averages (centered on each observation day) were applied on 2020 concentrations. The same procedure was followed for the 4 previous years in order to calculate a 4-year average value from the respective moving averages during 2016-2019.

Figure 5 shows the two generated time-series, as well as the corresponding minimum-maximum ranges for the 2016-2019 years. It is clear that for $\mathrm{NO}_{2}$ and $\mathrm{BC}_{\mathrm{ff}}$, during the lockdown period, concentrations were consistently lower than the corresponding minimums observed across the preceding 4 years. On the contrary, during the pre- and post-lockdown periods, the 2020 levels were mostly within the ranges (or higher) observed in the past. Following a completely different pattern, $\mathrm{BC}_{\mathrm{bb}}$ levels in 2020 displayed similar levels and a typically decreasing seasonal trend, as in the previous years.
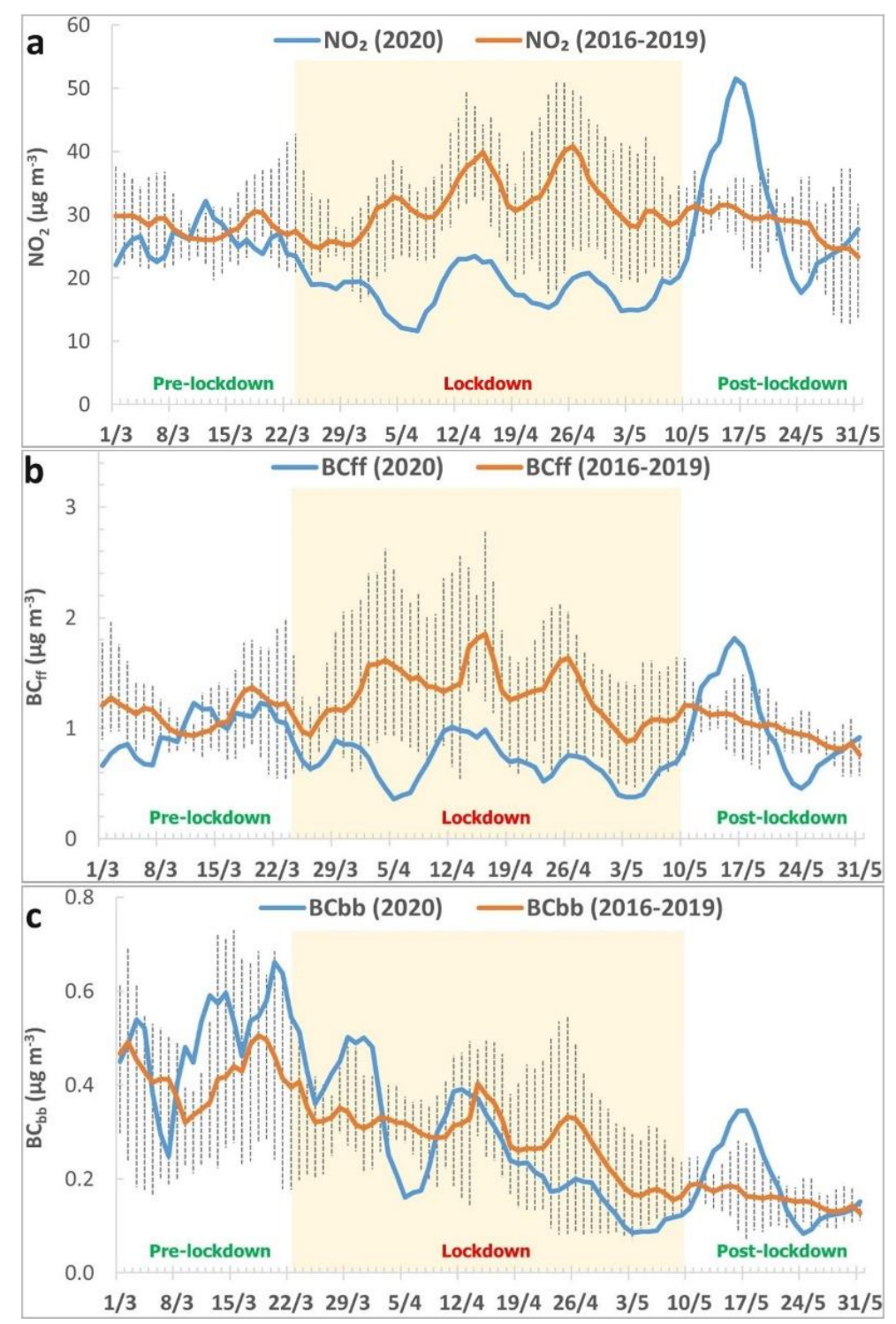

Figure 5. 7-day running mean for pollutant concentrations $(\mathbf{a}): \mathrm{NO}_{2},(\mathbf{b}): \mathrm{BC}_{\mathrm{ff}},(\mathbf{c}): \mathrm{BC}_{\mathrm{bb}}$, measured in 2020 and 2016-2019, in Athens (Thissio). Displaying 4-year averages of running mean values and minimum-maximum range (dashed-lines) for 2016-2019.

Detailed, period specific, statistics for $\mathrm{NO}_{2}, \mathrm{BC}, \mathrm{BC}_{\mathrm{ff}}$ and $\mathrm{BC}_{\mathrm{bb}}$ during 2016-2020 are provided in Table $\mathrm{S} 4$ of the Supplementary Material. It is observed that concentrations of traffic-related pollutants $\left(\mathrm{NO}_{2}, \mathrm{BC}_{\mathrm{ff}}\right)$ during $2016-2019$ were relatively stable among the three examined periods (pre-lockdown, 
lockdown, post-lockdown). However, this pattern was overturned in 2020 , with $\mathrm{NO}_{2}$ and $\mathrm{BC}_{\mathrm{ff}}$ levels decreasing significantly during the lockdown period, when the difference of concentrations compared to the 2016-2019 average was $42 \%$ and $47 \%$ for $\mathrm{NO}_{2}$ and $\mathrm{BC}_{\text {fff }}$, respectively. Conversely, small differences $(-10 \%$ to $+9 \%)$ were observed for the pre- and post-lockdown periods, between 2020 and 2016-2019. This considerable change in the concentration levels of 2020 during the period of interest, is further supported by the model findings. In particular, the reduction of the mean $\mathrm{NO}_{2}$ levels from 2019 to 2020 at the grid point of Thissio reaches $42 \%$ for the lockdown period, i.e., more than twice the one for the pre-lockdown period (18\%). As shown in Table S3 of the Supplementary Material, these differences are comparable to those corresponding to in situ measurements.

The majority of studies comparing the changes during the 2020 lockdowns in major cities, against control periods $2-5$ years in the past, has reported $\mathrm{NO}_{2}$ concentrations reduced by $30-60 \%[17,59,69]$. Also, a reduction of $47 \%$ compared to 2019 has been found for elemental carbon concentrations during the lockdown in Wuhan, China, mostly attributed to decreased emissions from vehicular sources [92]. In Southern European cities, Sicard et al. [22] documented decreases of 30-63\% at sites in Rome, Turin, Nice and Valencia, with respect to 2017-2019, which become lower if only non-traffic sites are considered. Baldasano [13] presented $\mathrm{NO}_{2}$ reductions in the range of $43-54 \%$ in Madrid and Barcelona, with respect to 2018 and 2019, highlighting also the importance of different meteorology between the compared years. Meteorological conditions along with the severity of confinement measures and the adherence of the population to their enforcement are important parameters for observed reductions in this type of analysis. For example, very large reductions ( $80 \%$ on average) for $\mathrm{NO}_{2}$ concentrations were observed in Quito (Ecuador), compared to 2018-2019, during a total lockdown period that included the full suspension of industrial production and public transportation [93]. Berman and Ebisu [12] in their study covering the contingent U.S. reported a mean reduction of $25 \%$ for $\mathrm{NO}_{2}$ levels against 2017-2019, with the mean reduction in counties that adopted late or no business closures being slightly lower (24\%). However, in cases where more relaxed "stay at home" measures were followed, such as in Memphis, $\mathrm{TN}$, where transportation of citizens was not restricted and businesses remained open, no air quality improvements were observed whatsoever [94].

\section{Conclusions}

This study analyzes the effects of the lockdown due to the COVID-19 pandemic on air pollution in Athens, Greece, exploiting the synergy between in situ measurements and city scale modeling. A thorough assessment of $\mathrm{NO}_{2}, \mathrm{CO}, \mathrm{CO}_{2}, \mathrm{PM}_{2.5}$ and $\mathrm{BC}$ concentration levels was performed for Spring 2020, in conjunction with meteorological parameters, to identify and quantify the lockdown-related changes in air quality conditions, in comparison to the pre- and the postlockdown periods, as well as against the preceding four years. The present study is among the first to explore the signal of the lockdown on urban $\mathrm{CO}_{2}$, allowing potential inferences regarding the effectiveness of climate change mitigation strategies on an urban scale. Under a new global economic model, such as the "Green Deal" discussed in Europe, this global experiment and up-scalable use cases, like the one presented here, can prove rather useful for informing decision making with data, delineating the chain between measures, emissions and air quality.

For all examined traffic-related pollutants, there was a statistically significant mean reduction during the lockdown in Athens (23 March-30 April 2020), when compared to the pre-lockdown period. In particular, $\mathrm{NO}_{2}$ decreased by $32 \%$ and $\mathrm{CO}$ by $35 \%$, while the $\mathrm{BC}_{\mathrm{ff}}$ fraction, associated with emissions from fossil fuel combustion, presented a similar decrease (33\%) as well. These observed reductions were highly dependent on reduced road transport in the urban zone. The fine aerosol fraction $\left(\mathrm{PM}_{2.5}\right)$ showed a smaller dependence on the cutbacks of emissions (18\% on average), as its greatest part is rather linked to atmospheric processing. Finally, urban $\mathrm{CO}_{2}$ monitoring provided interesting results, with a large reduction in the urban $\mathrm{CO}_{2}$ enhancement (58\%), indicative of significantly reduced total urban emissions. In the case of Athens, the levels of the studied air pollutants in Spring 2020 did not 
appear to be strongly dependent on meteorological irregularities or inter-annual trends. This constitutes an advantage of this study, as it was easier to identify and evaluate the lockdown effects.

A city scale air quality model was evaluated and deployed to simulate the lockdown effects on urban pollution. The motivation has been threefold: first, to simulate the meteorology-pollution conditions and evolution during the lockdown, in order to improve the quantification of the lockdown impacts; second, to confirm the, otherwise difficult to quantify through direct measurements, appropriate emission reduction scenario that matches the measurements; third, to produce geospatial information on the levels and patterns of pollution change within the Athens basin. The implementation of the reduced emissions scenario (which includes a $46 \%$ reduction in road transport as the main lockdown impact) resulted in $\mathrm{NO}_{2}$ mean concentration decreases of $30-40 \%$ over most of the Athens basin, in agreement with the reduction in levels of measured relevant traffic-related pollutants. Results from the hypothetical scenario of "business as usual" during the lockdown, indicated that at least $65 \%$ of this reduction can be attributed to the confinement conditions, the rest being linked to meteorology.

The rapid change of air pollution levels while passing from the pre-lockdown to the lockdown period and the immediate rebound of concentrations as soon as measures were lifted, hints at a viable direction for abatement of urban pollution. Strategies such as defining low-emission zones, reconsidering the percentage of vehicles allowed in city centers and promoting electro-mobility could prove rather efficient. For cities with pollution characteristics like those of Athens, such targeted interventions could help to eliminate exceedances of air quality standards, especially for $\mathrm{NO}_{2}$ and $\mathrm{PM}_{10}$, that are still observed at traffic sites. The successful synergy between modeling and in-situ measurements in a global, real-word experiment undertaken during the COVID-19 pandemic, provides confidence in modeling different pollution and climate change mitigation scenarios and can influence policy from city to regional scales. In the case of Athens, the findings can be considered representative of an extended urban area around the city center allowing for better informed urban planning. Other research directions in the framework of air quality studies under urban lockdown, may encompass the optimization of measures to tackle ozone exceedances by gaining insights on VOC- or $\mathrm{NO}_{\mathrm{x}}$ - limited atmospheric conditions driving ozone formation, or with detailed source apportionment studies coupled with modeling scenarios to obtain geospatially-resolved information on actual reductions of source contributions.

Supplementary Materials: The following are available online at http://www.mdpi.com/2073-4433/11/11/1174/s1, Figure S1: Map of the NOA/PANACEA low-cost $\mathrm{PM}_{2.5}$ monitoring network, Table S1: Statistics for meteorological parameters observed at Thissio, for years 2016-2020 and days corresponding to the pre-lockdown, lockdown and post-lockdown periods, Table S2: Concentrations of pollutants measured at Thissio, in 2020, during the pre-lockdown, lockdown and post-lockdown periods, Figure S2: Mean diurnal variability of pollutant concentrations, Table S3: Model performance metrics for $\mathrm{NO}_{2}$ and $\mathrm{PM}_{2.5}$, Figure S3: Satellite overview of the Attica peninsula during 13-15 May 2020, Figure S4: Potential source contribution (PSCF) plot for $\mathrm{PM}_{2.5}$, calculated for five-day air mass back-trajectories that arrived at Thissio during 15-18 May 2020, Table S4: Statistics for $\mathrm{NO}_{2}, \mathrm{BC}_{\text {, }}$ $\mathrm{BC}_{\mathrm{ff}}$ and $\mathrm{BC}_{\mathrm{bb}}$ measured at Thissio, for years 2016-2020 and days corresponding to the pre-lockdown, lockdown and post-lockdown periods of 2020.

Author Contributions: Conceptualization, G.G., E.A., E.L., N.M. and E.G.; methodology, G.G. and E.A.; formal analysis, G.G. and E.A.; investigation, G.G., E.A., A.K., E.L., I.S., P.K., A.B. and D.G.K.; data curation, G.G., E.A., E.L., I.S., A.B. and D.G.K.; writing-original draft preparation, G.G. and E.A.; writing—review and editing, G.G., E.A., J.B., E.L., M.R., N.M. and E.G.; supervision, N.M. and E.G.; project administration, N.M. and E.G.; funding acquisition, N.M. and E.G. All authors have read and agreed to the published version of the manuscript.

Funding: This research was funded by the project "PANhellenic infrastructure for Atmospheric Composition and climatE change" (MIS 5021516), which is implemented under the action "Reinforcement of the Research and Innovation Infrastructure", funded by the Operational Program "Competitiveness, Entrepreneurship and Innovation" (NSRF 2014-2020) and co-financed by Greece and the European Union (European Regional Development Fund). 
Acknowledgments: The study received support by ERA-PLANET (www.era-planet.eu) trans-national project SMURBS (www.smurbs.eu) (grant agreement no. 689443), funded under the EU Horizon 2020 Framework Program. We thank Horiba Ltd. and Envirosys Ltd. Environmental Applications-Technological Equipment, Athens, Greece, for making available the Horiba PX-375 Continuous Particulate Monitor that operated at the NOA Thissio site. We thank Maria Lianou and Fragiskos Pierros of IERSD/NOA for their valuable assistance with raw data processing and database compilation. We also thank the personnel of the Thissio and Finokalia monitoring stations. E.A. is grateful for the systematic collaboration with Martin Ramacher from the division 'Chemistry Transport Modelling' of the Institute of Coastal Research (HZG), who provided support and advice for the setup, configuration and implementation of the air pollution model.

Conflicts of Interest: The authors declare no conflict of interest.

\section{References}

1. Li, Q.; Guan, X.; Wu, P.; Wang, X.; Zhou, L.; Tong, Y.; Ren, R.; Leung, K.S.M.; Lau, E.H.Y.; Wong, J.Y.; et al. Early transmission dynamics in Wuhan, China, of novel coronavirus-infected pneumonia. N. Eng. J. Med. 2020, 382, 1199-1207. [CrossRef] [PubMed]

2. Wu, F.; Zhao, S.; Yu, B.; Chen, Y.-M.; Wang, W.; Song, Z.-G.; Hu, Y.; Tao, Z.-W.; Tian, J.-H.; Pei, Y.-Y.; et al. A new coronavirus associated with human respiratory disease in China. Nature 2020, 579, $265-269$. [CrossRef] [PubMed]

3. Kamenidou, I.E.; Stavrianea, A.; Liava, C. Achieving a Covid-19 free country: Citizens preventive measures and communication pathways. Int. J. Environ. Res. Public Health 2020, 17, 4633. [CrossRef] [PubMed]

4. NPHO. Daily Report of Epidemiological Surveillance for Infections with the New COVID-19 Coronavirus. National Public Health Organization. 2020. Available online: https://eody.gov.gr/wp-content/uploads/2020/ 10/covid-gr-daily-report-20201024.pdf (accessed on 24 October 2020). (In Greek)

5. Sohrabi, C.; Alsafi, Z.; O’Neill, N.; Khan, M.; Kerwan, A.; Al-Jabir, A.; Iosifidis, C.; Agha, R. World Health Organization declares global emergency: A review of the 2019 novel coronavirus (COVID-19). Int. J. Surg. 2020, 76, 71-76. [CrossRef]

6. Wu, C.; Chen, X.; Cai, Y.; Xia, J.; Zhou, X.; Xu, S.; Huang, H.; Zhang, L.; Zhou, X.; Du, C.; et al. Risk factors associated with acute respiratory distress syndrome and death in patients with coronavirus disease 2019 pneumonia in Wuhan, China. JAMA Intern. Med. 2020, 180, 934-943. [CrossRef]

7. Domingo, J.L.; Marquès, M.; Rovira, J. Influence of airborne transmission of SARS-CoV-2 on COVID-19 pandemic. A review. Environ. Res. 2020, 188, 109861. [CrossRef]

8. Liu, W.; Tao, Z.W.; Wang, L.; Yuan, M.-L.; Liu, K.; Zhou, L.; Wei, S.; Deng, Y.; Liu, J.; Liu, H.-G.; et al. Analysis of factors associated with disease outcomes in hospitalized patients with 2019 novel coronavirus disease. Chin. Med. J. 2020, 133, 1032-1038. [CrossRef] [PubMed]

9. Morawska, L.; Cao, J. Airborne transmission of SARS-CoV-2: The world should face the reality. Environ. Int. 2020, 139, 105730. [CrossRef] [PubMed]

10. Van Doremalen, N.; Bushmaker, T.; Morris, D.H.; Holbrook, M.G.; Gamble, A.; Williamson, B.N.; Tamin, A.; Harcourt, J.L.; Thornburg, N.J.; Gerber, S.I.; et al. Aerosol and surface stability of SARS-CoV-2 as compared with SARS-CoV-1. N. Eng. J. Med. 2020, 382, 1564-1567. [CrossRef]

11. Muhammad, S.; Long, X.; Salman, M. COVID-19 pandemic and environmental pollution: A blessing in disguise? Sci. Total Environ. 2020, 728, 138820. [CrossRef] [PubMed]

12. Ogen, Y. Assessing nitrogen dioxide $\left(\mathrm{NO}_{2}\right)$ levels as a contributing factor to coronavirus (COVID-19) fatality. Sci. Total Environ. 2020, 726, 138605. [CrossRef] [PubMed]

13. Baldasano, J.M. COVID-19 lockdown effects on air quality by $\mathrm{NO}_{2}$ in the cities of Barcelona and Madrid Spain. Sci. Total Environ. 2020, 741, 140353. [CrossRef]

14. Berman, J.D.; Ebisu, K. Changes in U.S. air pollution during the COVID-19 pandemic. Sci. Total Environ. 2020, 739, 139864. [CrossRef] [PubMed]

15. Zhang, Z.; Xue, T.; Jin, X. Effects of meteorological conditions and air pollution on COVID-19 transmission: Evidence from 219 Chinese cities. Sci. Total Environ. 2020, 741, 140244. [CrossRef] [PubMed]

16. Zhu, Y.; Xie, J.; Huang, F.; Cao, L. Association between short-term exposure to air pollution and COVID-19 infection: Evidence from China. Sci. Total Environ. 2020, 727, 138704. [CrossRef]

17. Xu, K.; Cui, K.; Young, L.-H.; Hsieh, Y.-K.; Wang, Y.-F.; Zhang, J.; Wan, S. Impact of the COVID-19 event on air quality in central China. Aerosol Air Qual. Res. 2020, 20, 915-929. [CrossRef] 
18. Sharma, S.; Zhang, M.; Anshika; Gao, J.; Zhang, H.; Kota, S.H. Effect of restricted emissions during COVID-19 on air quality in India. Sci. Total Environ. 2020, 728, 138878. [CrossRef] [PubMed]

19. He, G.; Pan, Y.; Tanaka, T. The short-term impacts of COVID-19 lockdown on urban air pollution in China. Nat. Sustain. 2020. [CrossRef]

20. Ma, C.-J.; Kang, G.-U. Air quality variation in Wuhan, Daegu, and Tokyo during the explosive outbreak of Covid-19 and its health effects. Int. J. Environ. Res. Public Health 2020, 17, 4119. [CrossRef]

21. Collivignarelli, M.C.; Abbà, A.; Bertanza, G.; Pedrazzani, R.; Ricciardi, P.; Carnevale Miino, M. Lockdown for CoViD-2019 in Milan: What are the effects on air quality? Sci. Total Environ. 2020, 732, 139280. [CrossRef]

22. Sicard, P.; De Marco, A.; Agathokleous, E.; Feng, Z.; Xu, X.; Paoletti, E.; Rodriguez, J.J.D.; Calatayud, V. Amplified ozone pollution in cities during the COVID-19 lockdown. Sci. Total Environ. 2020, 735, 139542. [CrossRef]

23. Tobías, A.; Carnerero, C.; Reche, C.; Massagué, J.; Via, M.; Minguillón, M.C.; Alastuey, A.; Querol, X. Changes in air quality during the lockdown in Barcelona (Spain) one month into the SARS-CoV-2 epidemic. Sci. Total Environ. 2020, 726, 138540. [CrossRef]

24. Menut, L.; Bessagnet, B.; Siour, G.; Mailler, S.; Pennel, R.; Cholakian, A. Impact of lockdown measures to combat Covid-19 on air quality over western Europe. Sci. Total Environ. 2020, 741, 140426. [CrossRef]

25. Chaloulakou, A.; Mavroidis, I.; Gavriil, I. Compliance with the annual $\mathrm{NO}_{2}$ air quality standard in Athens. Required $\mathrm{NO}_{\mathrm{x}}$ levels and expected health implications. Atmos. Environ. 2008, 42, 454-465. [CrossRef]

26. Gratsea, M.; Liakakou, E.; Mihalopoulos, N.; Adamopoulos, A.; Tsilibari, E.; Gerasopoulos, E. The combined effect of reduced fossil fuel consumption and increasing biomass combustion on Athens' air quality, as inferred from long term CO measurements. Sci. Total Environ. 2017, 592, 115-123. [CrossRef]

27. Grivas, G.; Cheristanidis, S.; Chaloulakou, A.; Koutrakis, P.; Mihalopoulos, N. Elemental composition and source apportionment of fine and coarse particles at traffic and urban background locations in Athens, Greece. Aerosol Air Qual. Res. 2018, 18, 1642-1659. [CrossRef]

28. Liakakou, E.; Stavroulas, I.; Kaskaoutis, D.G.; Grivas, G.; Paraskevopoulou, D.; Dumka, U.C.; Tsagkaraki, M.; Bougiatioti, A.; Oikonomou, K.; Sciare, J.; et al. Long-term variability, source apportionment and spectral properties of black carbon at an urban background site in Athens, Greece. Atmos. Environ. 2020, 222, 117137. [CrossRef]

29. Demertzis, K.; Tsiotas, D.; Magafas, L. Modeling and forecasting the COVID-19 temporal spread in Greece: An exploratory approach based on complex network defined splines. Int. J. Environ. Res. Public Health 2020, 17, 4693. [CrossRef]

30. Google. COVID-19 Community Mobility Report. Greece. Available online: https://www.gstatic.com/ covid19/mobility/2020-05-25_GR_Mobility_Report_en-1.pdf (accessed on 25 May 2020).

31. Le Quéré, C.; Jackson, R.B.; Jones, M.W.; Smith, A.J.P.; Abernethy, S.; Andrew, R.M.; De-Gol, A.J.; Willis, D.R.; Shan, Y.; Canadell, J.G.; et al. Temporary reduction in daily global $\mathrm{CO}_{2}$ emissions during the COVID-19 forced confinement. Nat. Clim. Chang. 2020, 10, 647-653. [CrossRef]

32. Progiou, A.G.; Ziomas, I.C. Road traffic emissions impact on air quality of the Greater Athens Area based on a 20year emissions inventory. Sci. Total Environ. 2011, 410-411, 1-7. [CrossRef]

33. Fameli, K.M.; Assimakopoulos, V.D. The new open Flexible Emission Inventory for Greece and the Greater Athens Area (FEI-GREGAA): Account of pollutant sources and their importance from 2006 to 2012. Atmos. Environ. 2016, 137, 17-37. [CrossRef]

34. Vrekoussis, M.; Richter, A.; Hilboll, A.; Burrows, J.P.; Gerasopoulos, E.; Lelieveld, J.; Barrie, L.; Zerefos, C.; Mihalopoulos, N. Economic crisis detected from space: Air quality observations over Athens/Greece. Geophys. Res. Lett. 2013, 40, 458-463. [CrossRef]

35. Theodosi, C.; Tsagkaraki, M.; Zarmpas, P.; Grivas, G.; Liakakou, E.; Paraskevopoulou, D.; Lianou, M.; Gerasopoulos, E.; Mihalopoulos, N. Multi-year chemical composition of the fine aerosol fraction in Athens, Greece, with emphasis on the contribution of residential heating in wintertime. Atmos. Chem. Phys. 2018, 18, 14371-14391. [CrossRef]

36. Stavroulas, I.; Bougiatioti, A.; Paraskevopoulou, D.; Grivas, G.; Liakakou, E.; Gerasopoulos, E.; Mihalopoulos, N. Sources and processes that control the submicron organic aerosol in an urban Mediterranean environment (Athens) using high temporal resolution chemical composition measurements. Atmos. Chem. Phys. 2019, 19, 901-919. [CrossRef] 
37. Grivas, G.; Stavroulas, I.; Liakakou, E.; Kaskaoutis, D.G.; Bougiatioti, A.; Paraskevopoulou, D.; Gerasopoulos, E.; Mihalopoulos, N. Measuring the spatial variability of Black Carbon in Athens during wintertime. Air Qual. Atmos. Health 2019, 12, 1405-1417. [CrossRef]

38. Kassomenos, P.; Flocas, H.A.; Lykoudis, S.; Petrakis, M. Analysis of mesoscale patterns in relation to synoptic conditions over an urban Mediterranean basin. Theor. Appl. Climatol. 1998, 59, 215-229. [CrossRef]

39. Kassomenos, P.; Kotroni, V.; Kallos, G. Analysis of climatological and air quality observations from Greater Athens Area. Atmos. Environ. 1995, 29, 3671-3688. [CrossRef]

40. Fourtziou, L.; Liakakou, E.; Stavroulas, I.; Theodosi, C.; Zarbas, P.; Psiloglou, B.; Sciare, J.; Maggos, T.; Bairachtari, K.; Bougiatioti, A.; et al. Multi-tracer approach to characterize domestic wood burning in Athens (Greece) during wintertime. Atmos. Environ. 2017, 148, 89-101. [CrossRef]

41. Panopoulou, A.; Liakakou, E.; Gros, V.; Sauvage, S.; Locoge, N.; Bonsang, B.; Psiloglou, B.E.; Gerasopoulos, E.; Mihalopoulos, N. Non Methane Hydrocarbons variability in Athens during wintertime: The role of traffic and heating. Atmos. Chem. Phys. 2018, 18, 16139-16154. [CrossRef]

42. Athanasopoulou, E.; Speyer, O.; Brunner, D.; Vogel, H.; Vogel, B.; Mihalopoulos, N.; Gerasopoulos, E. Changes in domestic heating fuel use in Greece: Effects on atmospheric chemistry and radiation. Atmos. Chem. Phys. 2017, 17, 10597-10618. [CrossRef]

43. Stavroulas, I.; Grivas, G.; Michalopoulos, P.; Liakakou, E.; Bougiatioti, A.; Kalkavouras, P.; Fameli, K.M.; Hatzianastassiou, N.; Mihalopoulos, N.; Gerasopoulos, E. Field evaluation of low-cost PM sensors (Purple Air PA-II) under variable urban air quality conditions, in Greece. Atmosphere 2020, 11, 926. [CrossRef]

44. Sandradewi, J.; Prevot, A.S.H.; Weingartner, E.; Schmidhauser, R.; Gysel, M.; Baltensperger, U. A study of wood burning and traffic aerosols in an Alpine valley using a multi-wavelength Aethalometer. Atmos. Environ. 2008, 42, 101-112. [CrossRef]

45. Drinovec, L.; Mocnik, G.; Zotter, P.; Prévôt, A.S.H.; Ruckstuhl, C.; Coz, E.; Rupakheti, M.; Sciare, J.; Müller, T.; Wiedensohler, A.; et al. The "dual-spot" Aethalometer: An improved measurement of aerosol black carbon with real time loading compensation. Atmos. Meas. Tech. 2015, 8, 1965-1979. [CrossRef]

46. Rella, C.W.; Chen, H.; Andrews, A.E.; Filges, A.; Gerbig, C.; Hatakka, J.; Karion, A.; Miles, N.L.; Richardson, S.J.; Steinbacher, M.; et al. High accuracy measurements of dry mole fractions of carbon dioxide and methane in humid air. Atmos. Meas. Tech. 2013, 6, 837-860. [CrossRef]

47. Kwok, C.Y.; Laurent, O.; Guemri, A.; Philippon, C.; Wastine, B.; Rella, C.W.; Vuillemin, C.; Truong, F.; Delmotte, M.; Kazan, V.; et al. Comprehensive laboratory and field testing of cavity ring-down spectroscopy analyzers measuring $\mathrm{H}_{2} \mathrm{O}, \mathrm{CO}_{2}, \mathrm{CH}_{4}$ and CO. Atmos. Meas. Tech. 2015, 89, 3867-3892. [CrossRef]

48. Hurley, P.; Physick, W.; Luhar, A. TAPM-A practical approach to prognostic meteorological and air pollution modelling. Environ. Model. Softw. 2005, 20, 737-752. [CrossRef]

49. Hurley, P. TAPM v. 4, Part 1: Technical Description; CSIRO Marine and Atmospheric Research Paper No. 25; CSIRO: Aspendale, Australia, 2008.

50. Hurley, P.J. An evaluation of several turbulence schemes for the prediction of mean and turbulent fields in complex terrain. Bound. Layer Meteorol. 1997, 83, 43-73. [CrossRef]

51. Hurley, P.J.; Luhar, A.K. The Kwinana coastal fumigation study: III-meteorological and turbulence modelling on selected days. Bound. Layer Meteorol. 2000, 94, 115-138. [CrossRef]

52. Hurley, P. The Air Pollution Model (TAPM) Version 2. Part 1: Technical Description; CSIRO Atmospheric Research Technical Paper No. 55; CSIRO: Aspendale, Australia, 2002.

53. Hurley, P.; Manins, P.; Lee, S.; Boyle, R.; Ng, Y.L.; Dewundege, P. Year-long, high-resolution, urban airshed modelling: Verification of TAPM predictions of smog and particles in Melbourne, Australia. Atmos. Environ. 2003, 37, 1899-1910. [CrossRef]

54. Luhar, A.K.; Hurley, P.J. Evaluation of TAPM, a prognostic meteorological and air pollution model, using urban and rural point-source data. Atmos. Environ. 2003, 37, 2795-2810. [CrossRef]

55. Karl, M.; Walker, S.-E.; Solberg, S.; Ramacher, M.O.P. The Eulerian urban dispersion model EPISODE-Part 2: Extensions to the source dispersion and photochemistry for EPISODE-CityChem v1.2 and its application to the city of Hamburg. Geosci. Model Dev. 2020, 12, 3357-3399. [CrossRef]

56. Tang, L.; Ramacher, M.O.P.; Moldanová, J.; Matthias, V.; Karl, M.; Johansson, L.; Jalkanen, J.-P.; Yaramenka, K.; Aulinger, A.; Gustafsson, M. The impact of ship emissions on air quality and human health in the Gothenburg area-Part 1: 2012 emissions. Atmos. Chem. Phys. 2019, 20, 7509-7530. [CrossRef] 
57. Gerasopoulos, E.; Athanasopoulou, E.; Ramacher, M.; Kakouri, A.; Speyer, O.; Karl, M.; Stavroulas, I.; Grivas, G.; Bailey, J. City scale air pollution modelling and high resolution exposure mapping of an urban hotspot in the Eastern Mediterranean. In Proceedings of the AGU Fall Meeting 2020, San Francisco, CA, USA, 7-11 December 2019. A13Q-3154.

58. Ramacher, M.O.P.; Karl, M. Integrating modes of transport in a dynamic modelling approach to evaluate population exposure to ambient $\mathrm{NO}_{2}$ and $\mathrm{PM}_{2.5}$ pollution in urban areas. Int. J. Environ. Res. Public Health 2020, 17, 2099. [CrossRef] [PubMed]

59. Kerimray, A.; Baimatova, N.; Ibragimova, O.P.; Bukenov, B.; Kenessov, B.; Plotitsyn, P.; Karaca, F. Assessing air quality changes in large cities during COVID-19 lockdowns: The impacts of traffic-free urban conditions in Almaty, Kazakhstan. Sci. Total Environ. 2020, 730, 139179. [CrossRef] [PubMed]

60. Chaloulakou, A.; Kassomenos, P.; Grivas, G.; Spyrellis, N. Particulate matter and black smoke concentration levels in central Athens, Greece. Environ. Int. 2005, 31, 651-659. [CrossRef]

61. Elminir, H.K. Dependence of urban air pollutants on meteorology. Sci. Total Environ. 2005, 350, 225-237. [CrossRef]

62. Chate, D.M.; Pranesha, T.S. Field studies of scavenging of aerosols by rain events. J. Aerosol Sci. 2004, 35, 695-706. [CrossRef]

63. Founda, D.; Giannakopoulos, C.; Pierros, F.; Kalimeris, A.; Petrakis, M. Observed and projected precipitation variability in Athens over a 2.5 century period. Atmos. Sci. Lett. 2013, 14, 72-78. [CrossRef]

64. Grivas, G.; Dimakopoulou, K.; Papakosta, D.; Karakatsani, A.; Katsouyanni, K.; Chaloulakou, A. Ozone exposure assessment for children in Greece: Results from the RESPOZE study. Sci. Total Environ. 2017, 581-582, 518-529. [CrossRef]

65. Grivas, G.; Chaloulakou, A.; Samara, C.; Spyrellis, N. Spatial and temporal variation of PM 10 mass concentrations within the greater area of Athens, Greece. Water Air Soil Pollut. 2004, 158, 357-371. [CrossRef]

66. Cyrys, J.; Eeftens, M.; Heinrich, J.; Ampe, C.; Armengaud, A.; Beelen, R.; Bellander, T.; Beregszaszi, T.; Birk, M.; Cesaroni, G.; et al. Variation of $\mathrm{NO}_{2}$ and $\mathrm{NO}_{x}$ concentrations between and within 36 European study areas: Results from the ESCAPE study. Atmos. Environ. 2012, 62, 374-390. [CrossRef]

67. Mahato, S.; Pal, S.; Ghosh, K.G. Effect of lockdown amid COVID-19 pandemic on air quality of the megacity Delhi, India. Sci. Total Environ. 2020, 730, 139086. [CrossRef] [PubMed]

68. Dantas, G.; Siciliano, B.; França, B.B.; da Silva, C.M.; Arbilla, G. The impact of COVID-19 partial lockdown on the air quality of the city of Rio de Janeiro, Brazil. Sci. Total Environ. 2020, 729, 139085. [CrossRef]

69. Nakada, L.Y.K.; Urban, R.C. COVID-19 pandemic: Impacts on the air quality during the partial lockdown in São Paulo state, Brazil. Sci. Total Environ. 2020, 730, 13908. [CrossRef] [PubMed]

70. Safarian, S.; Unnthorsson, R.; Richter, C. Effect of coronavirus disease 2019 on $\mathrm{CO}_{2}$ emission in the world. Aerosol Air Qual. Res. 2020, 20, 1197-1203. [CrossRef]

71. Gioli, B.; Toscano, P.; Lugato, E.; Matese, A.; Miglietta, F.; Zaldei, A.; Vaccari, F.P. Methane and carbon dioxide fluxes and source partitioning in urban areas: The case study of Florence, Italy. Environ. Pollut. 2020, 164, 125-131. [CrossRef] [PubMed]

72. Stagakis, S.; Chrysoulakis, N.; Spyridakis, N.; Feigenwinter, C.; Vogt, R. Eddy Covariance measurements and source partitioning of $\mathrm{CO}_{2}$ emissions in an urban environment: Application for Heraklion, Greece. Atmos. Environ. 2019, 201, 278-292. [CrossRef]

73. Xueref-Remy, I.; Dieudonné, E.; Vuillemin, C.; Lopez, M.; Lac, C.; Schmidt, M.; Delmotte, M.; Chevallier, F.; Ravetta, F.; Perrussel, O.; et al. Diurnal, synoptic and seasonal variability of atmospheric $\mathrm{CO}_{2}$ in the Paris megacity area. Atmos. Chem. Phys. 2018, 18, 3335-3362. [CrossRef]

74. Paraskevopoulou, D.; Liakakou, E.; Gerasopoulos, E.; Mihalopoulos, N. Sources of atmospheric aerosol from long-term measurements (5 years) of chemical composition in Athens, Greece. Sci. Total Environ. 2015, 527-528, 165-178. [CrossRef] [PubMed]

75. Dimitriou, K.; Grivas, G.; Liakakou, E.; Gerasopoulos, E.; Mihalopoulos, N. Assessing the contribution of regional sources to urban 1 air pollution by applying 3D-PSCF modeling. Atmos. Res. 2021, 248, 105187. [CrossRef]

76. Gerasopoulos, E.; Amiridis, V.; Kazadzis, S.; Kokkalis, P.; Eleftheratos, K.; Andreae, M.O.; Andreae, T.W.; El-Askary, H.; Zerefos, C.S. Three-year ground based measurements of aerosol optical depth over the Eastern Mediterranean: The urban environment of Athens. Atmos. Chem. Phys. 2011, 11, 2145-2159. [CrossRef]

77. Rodríguez-Urrego, D.; Rodríguez-Urrego, L. Air quality during the COVID-19: $\mathrm{PM}_{2.5}$ analysis in the 50 most polluted capital cities in the world. Environ. Pollut. 2020, 266, 115042. [CrossRef] 
78. Adams, M.D. Air pollution in Ontario, Canada during the COVID-19 State of Emergency. Sci. Total Environ. 2020, 742, 140516. [CrossRef]

79. Bao, R.; Zhang, A. Does lockdown reduce air pollution? Evidence from 44 cities in northern China. Sci. Total Environ. 2020, 731, 139052. [CrossRef] [PubMed]

80. Athanasopoulou, E.; Tombrou, M.; Russell, A.G.; Karanasiou, A.; Eleftheriadis, K.; Dandou, A. Implementation of road and soil dust emission parameterizations in the aerosol model CAMx: Applications over the greater Athens urban area affected by natural sources. J. Geophys. Res. 2010, 115, D17301. [CrossRef]

81. Koukouli, M.-E.; Skoulidou, I.; Karavias, A.; Parcharidis, I.; Balis, D.; Manders, A.; Segers, A.; Eskes, H.; van Geffen, J. Sudden changes in nitrogen dioxide emissions over Greece due to lockdown after the outbreak of COVID-19. Atmos. Chem. Phys. Discuss. 2020. [CrossRef]

82. Mavroidis, I.; Chaloulakou, A. Long-term trends of primary and secondary $\mathrm{NO}_{2}$ production in the Athens area. Variation of the $\mathrm{NO}_{2} / \mathrm{NO}_{\mathrm{x}}$ ratio. Atmos. Environ. 2011, 45, 6872-6879. [CrossRef]

83. Siciliano, B.; Dantas, G.; da Silva, C.M.; Arbilla, G. Increased ozone levels during the COVID-19 lockdown: Analysis for the city of Rio de Janeiro, Brazil. Sci. Total Environ. 2020, 737, 139765. [CrossRef] [PubMed]

84. Mahato, S.; Ghosh, K.G. Short-term exposure to ambient air quality of the most polluted Indian cities due to lockdown amid SARS-CoV-2. Environ. Res. 2020, 188, 109835. [CrossRef] [PubMed]

85. Cui, Y.; Ji, D.; Maenhaut, W.; Gao, W.; Zhang, R.; Wang, Y. Levels and sources of hourly PM 2.5 -related elements during the control period of the COVID-19 pandemic at a rural site between Beijing and Tianjin. Sci. Total Environ. 2020, 744, 140840. [CrossRef] [PubMed]

86. EEA. Healthy Environment, Healthy Lives: How the Environment Influences Health and Well-Being in Europe; European Environmental Agency EEA Report No 21\2019; Publications Office of the European Union: Luxembourg, 2020. Available online: https://www.eea.europa.eu/publications/healthy-environment-healthylives (accessed on 23 September 2020).

87. Jenkin, M.E.; Clemitshaw, K.C. Ozone and other secondary photochemical pollutants: Chemical processes governing their formation in the planetary boundary layer. Atmos. Environ. 2020, 34, 2499-2527. [CrossRef]

88. Hatzianastassiou, N.; Katsoulis, B.D.; Antakis, B. Extreme nitrogen oxide and ozone concentrations in Athens atmosphere in relation to meteorological conditions. Environ. Monit. Assess. 2007, 127, 447-464. [CrossRef] [PubMed]

89. Remoundaki, E.; Kassomenos, P.; Mantas, E.; Mihalopoulos, N.; Tsezos, M. Composition and mass closure of $\mathrm{PM}_{2.5}$ in urban environment (Athens, Greece). Aerosol Air Qual. Res. 2020, 13, 72-82. [CrossRef]

90. Zangari, S.; Hill, D.T.; Charette, A.T.; Mirowsky, J.E. Air quality changes in New York City during the COVID-19 pandemic. Sci. Total Environ. 2020, 742, 140496. [CrossRef]

91. NCESD. Greece: State of the Environment Report; National Center for the Environment and Sustainable Development (NCESD): Athens, Greece, 2020; pp. 33-34. Available online: https://ekpaa.ypeka.gr/ektheseis/ soer-2018 (accessed on 23 September 2020).

92. Zambrano-Monserrate, M.A.; Ruano, M.A. Has air quality improved in Ecuador during the COVID-19 pandemic? A parametric analysis. Air Qual. Atmos. Health 2020, 13, 929-938. [CrossRef]

93. Zheng, H.; Kong, S.; Chen, N.; Yan, Y.; Liu, D.; Zhu, B.; Xu, K.; Cao, W.; Ding, Q.; Lan, B.; et al. Significant changes in the chemical compositions and sources of $\mathrm{PM}_{2.5}$ in Wuhan since the city lockdown as COVID-19. Sci. Total Environ. 2020, 739, 140000. [CrossRef]

94. Jia, C.; Fu, X.; Bartelli, D.; Smith, L. Insignificant impact of the "stay-at-home" order on ambient air quality in the Memphis Metropolitan Area, U.S.A. Atmosphere 2020, 11, 630. [CrossRef]

Publisher's Note: MDPI stays neutral with regard to jurisdictional claims in published maps and institutional affiliations.

(C) 2020 by the authors. Licensee MDPI, Basel, Switzerland. This article is an open access article distributed under the terms and conditions of the Creative Commons Attribution (CC BY) license (http://creativecommons.org/licenses/by/4.0/). 